\title{
ACPD
}

\section{Atmospheric winter conditions 2007/08 over the Arctic Ocean based on NP-35 data and regional model simulations}

M. Mielke ${ }^{1}$, N. S. Zinoviev ${ }^{2}$, K. Dethloff ${ }^{1}$, A. Rinke ${ }^{1}$, V. J. Kustov ${ }^{2}$, A. P. Makshtas ${ }^{2}$, V. T. Sokolov ${ }^{2}$, R. Neuber ${ }^{1}$, M. Maturilli ${ }^{1}$, D. Klaus ${ }^{1}$, D. Handorf ${ }^{1}$, and J. Graeser ${ }^{1}$

${ }^{1}$ Alfred Wegener Institute, Helmholtz Centre for Polar- and Marine Research, AWI Potsdam, Germany

${ }^{2}$ Arctic and Antarctic Research Institute, AARI, St. Petersburg, Russia

Received: 29 January 2014 - Accepted: 20 April 2014 - Published: 12 May 2014

Correspondence to: K. Dethloff (klaus.dethloff@awi.de)

Published by Copernicus Publications on behalf of the European Geosciences Union.

Atmospheric winter conditions 2007/08

M. Mielke et al.

Title Page

\section{Full Screen / Esc}




\section{Abstract}

Atmospheric measurements on the drifting Arctic sea ice station "North Pole-35" crossing the Eastern part of the Arctic Ocean during winter 2007/2008 have been compared with regional atmospheric HIRHAM model simulations. The observed near-surface 5 temperature, mean sea level pressure and the vertical temperature, wind and humidity profiles are satisfactorily reproduced by the model. The strongest temperature differences between observations and the simulations occur near the surface due to an overestimated vertical mixing of heat in the stable Arctic boundary layer (ABL). The observations show very strong temperature inversions near the surface, whereas the simulated inversions occur frequently between the surface and $415 \mathrm{~m}$ at too high levels. The simulations are not able to reproduce the observed inversion strength. The regional model underestimates the wind speeds and the sharp vertical wind gradients. The strength of internal atmospheric dynamics on the temporal development of atmospheric surface variables and vertical profiles of temperature, wind and relative humidity has been examined. Although the HIRHAM model systematically overestimates relative humidity and produces too high long-wave downward radiation during winter, two different atmospheric circulation states, which are connected to higher or lower pressure systems over the Eastern part of the Arctic Ocean, are simulated in agreement with the NP-35 observations. Sensitivity studies with reduced vertical mixing of heat in the stable ABL have been carried out. A slower increase in the stability functions with decreasing Richardson number under stable stratification has an impact on the horizontal and vertical atmospheric structure. Changes in synoptical cyclones on time scales from 1-3 days over the North Atlantic cyclone path are generated, which influences the atmospheric baroclinic and planetary waves on time scales up to 20 25 days over the Arctic Ocean basin. The use of increased vertical stability in the model simulation leads to diminished planetary-scale variability over the Arctic Ocean.
ACPD

$14,11855-11893,2014$

Atmospheric winter conditions 2007/08

M. Mielke et al.

Title Page

Abstract Introduction

Conclusions References

Tables Figures

14 $\Delta$

4

Back

Full Screen / Esc

Printer-friendly Version

Interactive Discussion 


\section{Introduction}

The winter atmosphere over the ice covered Arctic Ocean is characterized by surfacebased temperature inversions and low-level wind jets as estimated by Zhang and Seidel (2011). Due to the remote location and the harsh climatic conditions in this area, 5 a lack of systematic atmospheric observations exists, which limits progress in understanding the structure and variability of the near-surface climate, the ABL and the interaction with baroclinic pressure systems in the free troposphere over the Arctic Ocean.

State-of-the-art Arctic regional climate models (RCMs) suffer from poorly described regional feedbacks due to insufficient atmospheric subgrid-scale parameterizations.

10 Tjernström et al. (2005), Rinke et al. (2006) and Wyser et al. (2008) evaluated the performance of an ensemble of eight RCMs through comparison with data from the Surface Heat Budget of the Arctic Ocean (SHEBA) experiment in the Beaufort Sea from September 1997 until October 1998. The largest deviations between observations and simulations were found near the surface and in the ABL. The model scatter was 15 associated with insufficient parameterizations of surface albedo, surface fluxes, the turbulence in the stable ABL and clouds. Since the vertical mixing in the stable ABL over the Arctic Ocean, the coupling of the $A B L$ with baroclinic cyclones and the large-scale atmospheric circulation is not yet fully understood, more reliable data are the basis to reduce the uncertainties in the model simulations. Ten years after the SHEBA experiment, Vihma et al. (2007) reported on the measurements of atmospheric conditions over the Arctic Ocean during spring and summer 2007 in the frame of the European project "Developing Arctic Modeling and Observing Capabilities for Long-term Environmental Studies" (DAMOCLES) described by Gascard et al. (2008).

Recently Atlaskin and Vihma (2012) evaluated the performance of four operational 25 numerical weather prediction models (NWPs) conducting winter simulations from 1 December 2009 until 1 March 2010 for Europe and Northern Finland. They reported on a $2 \mathrm{~m}$ temperature bias and significant differences between modelled and measured vertical temperature profiles in the lower atmospheric layer up to $32 \mathrm{~m}$ as a result
ACPD

14, 11855-11893, 2014

Atmospheric winter conditions 2007/08

M. Mielke et al.

Title Page
Abstract

Conclusions

Tables

14

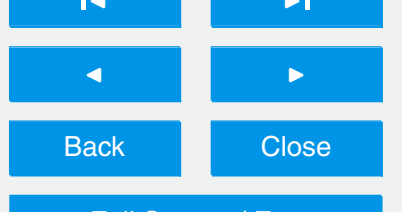

Full Screen / Esc
Interactive Discussion 
of overestimated model turbulence under very stable conditions. Tastula et al. (2012) evaluated the performance of the polar WRF over Antarctic sea ice for autumn and winter conditions from 21 February until 4 June 1992 and demonstrated the difficulties of models in simulating low-level jets over sea ice. They further showed that model bi5 ases in the surface temperatures and the near-surface turbulent fluxes are connected with poor simulations of cloud cover.

Since global models show largest biases in polar regions, RCMs with higher horizontal resolution have been used as a test bed for improving parameterizations of subgrid-scale processes (e.g. Tjernström et al., 2005; Rinke et al., 2006; Wyser et al., 10 2008). Validation studies of pan-Arctic RCMs (e.g., Rinke et al., 2009; Cassano et al., 2011) demonstrated the current model skills and the sensitivity of the results to the model physical parameterizations as well as the need of careful model evaluation as a prerequisite for improving the models. Rinke and Dethloff (2000), Rinke et al. (2004) and Laprise et al. (2008) discussed the role of initial and boundary conditions on the 15 performance of RCMs, where smaller and meso-scales are generated for given lateral boundary conditions. Internal variability often assumed to be negligible in one-way nested models due to the control exerted by the imposed lateral boundary conditions might be very strong, depending on the applied domain size.

The aim of this paper is to represent and analyse the unique atmospheric observations carried out on the Arctic sea ice drifting station "North Pole-35" (NP-35) during the extended winter period from 1 November 2007 until 31 March 2008 and to compare this observational data with RCM simulations based on the HIRHAM model. Biases and shortcomings in the model performance have been evaluated, and the impact of changed stability functions in the ABL for more stable stratification has been investigated following a suggestion of Grachev et al. (2007). The NP-35 observations are similar to the atmospheric observations on the Arctic drifting station Tara from March to September 2007 described by Vihma et al. (2008).

The structure of the current paper is as follows: in Sect. 2, the available surface, $A B L$ and upper air atmospheric observations and in Sect. 3 the applied RCM HIRHAM

Atmospheric winter conditions 2007/08

M. Mielke et al.

Title Page

Abstract

Conclusions

Tables

14

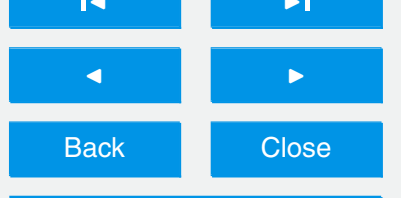

Full Screen / Esc

Printer-friendly Version

Interactive Discussion 
are described. Section 4 presents their comparison and contains evaluation results. Section 5 summarizes the results and concludes about future model improvements.

\section{Atmospheric observations on the ice drifting station "North Pole-35"}

As part of observations during the International Polar Year (IPY) the Russian sea ice drifting station "North Pole-35" was built and opened for the international science community by the Arctic and Antarctic Research Institute (AARI) St. Petersburg on a seaice floe over the Arctic Ocean. From 21 September $2007\left(81^{\circ} 27^{\prime} \mathrm{N} 115^{\circ} 19^{\prime} \mathrm{E}\right)$ until 13 July $2008\left(81^{\circ} 15^{\prime} \mathrm{N} 029^{\circ} 15^{\prime} \mathrm{E}\right) \mathrm{NP}-35$ drifted across the Arctic Ocean.

Figure 1 shows the NP-35 trajectory within the integration domain of the regional climate model HIRHAM, used for the model simulations. In order to understand the interaction between sea ice, $\mathrm{ABL}$ and baroclinic cyclones in the free troposphere, continuous measurements have been carried out from September 2007 until July 2008, including measurements of sea-ice thickness, standard meteorological parameters, surface radiation budget, and vertical atmospheric profiles. Atmospheric measurements to measure vertical profiles of air temperature, relative humidity, wind speed, and wind direction in the $A B L$ and the free troposphere.

The near-surface values have been measured by the meteorological station MAWS110 (Vaisala, Finland) on a $10 \mathrm{~m}$ high measuring tower. The air temperature and relative humidity were measured at 2 and $8 \mathrm{~m}$, and the wind speed at 2 and $10 \mathrm{~m}$ height, respectively, while the wind direction was only observed at $10 \mathrm{~m}$. The shortwave (SW) and long-wave (LW) radiative flux components were measured by the heated net-radiometer CNR-1 (Kipp \& Zonen, Netherlands) in $2 \mathrm{~m}$ height. Both the data of meteorological and radiation parameters have been acquired with a temporal resolution of $1 \mathrm{~min}$. All analyzed quantities and their accuracy are presented in Table 1. For the analysis of tethered balloon and radiosonde measurements no interpolated but edited raw data had been used. Before the estimation of hourly averaged

ACPD

$14,11855-11893,2014$

Atmospheric winter conditions 2007/08

M. Mielke et al.

Title Page

Abstract Introduction

Conclusions References

Tables Figures

14 $\Delta$

4

Back

Full Screen / Esc

Printer-friendly Version

Interactive Discussion 
meteorological parameters their values during each hour were controlled, and on this basis, current values exceeding 3 standard deviations had been deleted from the calculations. To take account of the influence of a rimy radiation sensor on hourly data, the graphs of actual data for each day had been controlled visually by comparison with

5 appropriate data after clearing of rime, where the latter was done hour by hour. In case of strong riming, the hourly data had been estimated from linear interpolation between values obtained immediately after sensor cleaning. Cloudiness had been estimated from 3 hourly visual observations.

Upper air measurements of pressure, temperature, relative humidity, wind speed 10 and wind direction have been carried out twice daily (00:00 and 12:00 UTC) with the sounding system Vaisala Digicora III with RS-92 type probe (Vaisala, Finland). Here, the 6 hourly, daily and monthly mean NP-35 measurements are used to evaluate the HIRHAM RCM simulations for the extended winter period from 1 November 2007 to 31 March 2008.

\section{Regional atmospheric model HIRHAM for the Arctic}

For the model simulations the atmospheric RCM "HIRHAM" has been applied with its pan-Arctic integration domain (see Fig. 1) as described by Rinke et al. (2006). This hydrostatic primitive-equation model contains the physical parameterization package of ECHAM4 (Roeckner et al., 1996). A description of the model has been given in the above-mentioned publications, and can also be found in Dethloff et al. (1996). The radiation package was adopted from the ECMWF model (Morcrette et al., 1986) including some modifications. The surface turbulent fluxes are calculated from a bulk transfer parameterization based on Monin-Obukhov similarity theory following Louis (1979). The transfer coefficients for momentum and heat depend on roughness length and a bulk
Richardson number for stable and unstable conditions and apply the formulations ofBrinkop and Roeckner (1995). The values of the roughness lengths for momentum and
ACPD

$14,11855-11893,2014$

Atmospheric winter conditions 2007/08

M. Mielke et al.

Title Page
Abstract

Conclusions

Tables

14

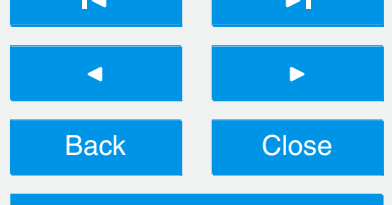

Full Screen / Esc
Printer-friendly Version

Interactive Discussion 
heat are equal $\left(1 \times 10^{-3} \mathrm{~m}\right)$, but differing stability functions for momentum and heat are applied.

The transfer coefficients for heat and momentum depend on the roughness length, the bulk Richardson number $R i$ and stability functions $g_{h, m}$, empirically specified for 5 the different stability conditions as displayed in Fig. 2 . For stable cases $(R i>0)$ they are $g_{h}=1 /[1+3 b R i \sqrt{1+5 R i}]$ and $g_{m}=1 /[1+2 b R i / \sqrt{1+5 R i}]$, using a default tuning parameter of $b=5$. A value of $b=10$ was applied in selected sensitivity experiments for more stable stratification, where the stability functions increase more slowly with decreasing Richardson number as pointed out by Grachev et al. (2007). Above the surface layer a higher-order closure scheme has been applied to parameterize the vertical turbulent mixing with exchange coefficients calculated as functions of turbulent kinetic energy (Brinkop and Roeckner, 1995).

For the heat budget calculation over ice, the surface albedo of snow and ice surfaces is parameterized as linear function of the surface temperature. The model uses a hori5 zontal resolution of $0.5^{\circ}$, which corresponds to ca. $55 \mathrm{~km}$ and a vertical resolution with a total of 25 levels and 10 levels in the lowest $600 \mathrm{~m}$. The ECMWF operational analysis with a T399 triangular truncation corresponding to a horizontal resolution of ca. $55 \mathrm{~km}$ has been used for forcing at the lateral boundaries, updated 6 hourly, and at the ocean lower boundary, the sea surface temperatures and sea ice fractions are updated daily. 20 Fractional sea ice coverage was taken into account, and ice thickness was prescribed to the averaged value of $2 \mathrm{~m}$ measured on NP-35. The sea-ice surface temperatures are calculated by a heat balance equation.

The model was run either in the climate mode or in the forecast mode. In the climate mode an ensemble of 5 simulations each month long with slightly different initial condi25 tions in the atmosphere have been carried out, where the initial conditions have been shifted by $\pm 12, \pm 6$ and $0 \mathrm{~h}$. The climate simulations, which started at 00:00 UTC are called "HIRHAM clima" and the ensemble mean of the simulations with the 5 different initial conditions is called "HIRHAM ens". Both HIRHAM clima and HIRHAM ens apply a default value of $b=5$ in the ABL stability function calculations, whereas simulations

Atmospheric winter conditions 2007/08

M. Mielke et al.

Title Page

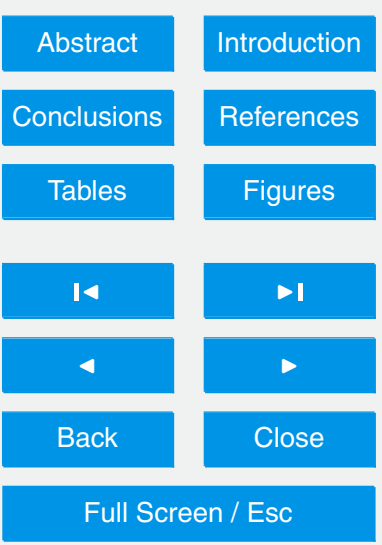

Printer-friendly Version

Interactive Discussion

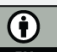


with changed stability functions use $b=10$, called "HIRHAM b10". The NP-35 data have not been taken into account for the ECMWF data assimilation and not been used in the ECMWF analysis system. The forecast run ("HIRHAM f12") was re-initialized every $12 \mathrm{~h}$ from the operational ECMWF analyses. The forecast mode has been ap5 plied with the aim to stay close to the observed weather situations. The vertical profiles of air temperature during NP-35 (observations, climate mode HIRHAM ens, HIRHAM clima, HIRHAM b10, and forecast mode HIRHAM f12) were compared on the basis of the sounding data and models calculation twice daily (00:00 UTC and 12:00 UTC). The model simulations have been horizontally interpolated for the current NP-35 position 10 and vertically for a resolution of $25 \mathrm{hPa}$.

\section{Measurements and comparison with HIRHAM simulations}

\subsection{Comparison of near surface variables}

For the analyzed period November 2007 to March 2008, the daily average of the NP35 surface-based observations of $2 \mathrm{~m}$ air temperature, relative humidity, wind speed

at $10 \mathrm{~m}$, and surface net LW radiation have been compared with the corresponding HIRHAM model ensemble simulations including their standard deviations (Fig. 3), interpolated for the NP-35 position. In our convention positive radiative LW fluxes are upward directed and describe radiative cooling. The overall temporal changes of $2 \mathrm{~m}$ temperature, $10 \mathrm{~m}$ wind and surface net LW radiation are well simulated, with the forecast simulations in much better agreement as a result of the 12 hourly re-initialization. However, deviations of up to $15 \mathrm{~K}$ are found in the $2 \mathrm{~m}$ temperature during several periods especially during January and February 2008. The computed correlations between simulation and observation, presented in Table 2, range from 0.75 for HIRHAM f12 to 0.45 for HIRHAM ens. The across-ensemble scatter in simulated $2 \mathrm{~m}$ air temperature, humidity. The relatively large magnitude of the across-ensemble scatter shows, that

ACPD

$14,11855-11893,2014$

Atmospheric winter conditions 2007/08

M. Mielke et al.

Title Page

Abstract

Introduction

Conclusions

References

Tables

Figures

14

I

4

Back

Full Screen / Esc

Printer-friendly Version

Interactive Discussion 
the RCM simulations are only partly determined by the lateral boundary conditions and internal variability is important, which reflects the impact of different initial conditions on the ensemble members. The scatter following internally generated variability adds to the differences between members of an ensemble of simulations, that results 5 from changes in tunable model parameters $(b=5$ or 10$)$ and different parameterization packages displayed in the Figs. 5 and 6.

Furthermore, Fig. 3 reveals that measured winter changes in relative humidity are not well reproduced by the model. There is a systematic model overestimation compared to observations and no correlation between the simulations and the observations

\section{November $2007-M a r c h ~ 2008$ at NP-35, based on HIRHAM ensemble members has} been checked and shows a very high correlation for relative humidity below $100 \%$. This militates for an observational deficit of the humidity sensor at low temperatures, e.g. loss of the sensor sensitivity for temperatures below $-30^{\circ} \mathrm{C}$.

15 During polar night conditions the HIRHAM model simulates too high relative humidity and too high net LW radiation. The correlation between the cloud observations and model simulations is very low. The erroneous presence of clouds in the HIRHAM simulations causes a positive bias in surface long wave downward radiation (LWD) during cold periods as pointed out earlier by Wyser et al. (2008). Rinke et al. (2012) showed, that the rate of increase of LWD with cloud cover is overestimated in the HIRHAM model for winter, which is consistent with an excess of cloud liquid water and hence thermal emissivity for large cloud fractions. LW radiative HIRHAM simulation errors are therefore obvious for winter conditions also discussed by Klaus et al. (2012) with a single column version of HIRHAM along the NP-35 trajectory. Therefore, the LW radiation differences between simulations and observations reach often more than $100 \%$. The HIRHAM 12 simulations are always in closer agreement with the NP-35 measurements and operational ECMWF analysis. The day-to-day changes of the $10 \mathrm{~m}$ wind speed are well simulated by HIRHAM 12 with a correlation of 0.81 but only 0.35 for HIRHAM ens. Temporarily large deviations of up to $5-6 \mathrm{~m} \mathrm{~s}^{-1}$ occur in the climate mode simulations.

\section{ACPD}

$14,11855-11893,2014$

Atmospheric winter conditions 2007/08

M. Mielke et al.

Title Page

Abstract

Introduction

Conclusions

References

Tables

Figures

14

$\Delta$

4

Back

$>$

Close

Full Screen / Esc

Printer-friendly Version

Interactive Discussion 
Table 2 summarizes the means of surface variables measured on NP-35 and simulated by the model for the period November 2007-March 2008. Furthermore, it contains their correlations and root mean square errors. The highest correlations exist for the mean sea level pressure, $2 \mathrm{~m}$ temperature and the $2 \mathrm{~m}$ dew point temperature.

5 The HIRHAM f12 simulations additionally indicate a good correlation for the $10 \mathrm{~m}$ wind speed. The deviations in the relative humidity between model simulations and observations during the extended winter arise due to differences between the $2 \mathrm{~m}$ temperature and the $2 \mathrm{~m}$ dew point temperature which are $2.9 \mathrm{~K}$ in the measurements, $1.1 \mathrm{~K}$ for HIRHAM f12 and $0.9 \mathrm{~K}$ for HIRHAM ens.

10 It is essential that the model captures the observed Arctic synoptic-scale pressure systems, otherwise erroneous simulated wind and turbulent fluxes could occur. Therefore, the variability of the surface pressure, $2 \mathrm{~m}$ temperature and $10 \mathrm{~m}$ wind speed on time scales between 2 and 30 days in the observations, HIRHAM ens mean and HIRHAM f12 simulations has been analyzed and compared. Figure 4 displays the local wavelet spectra (e.g. Torrence and Campo, 1998), based on daily data. The wavelet transformation was performed with the Morlet wavelet. It quantitatively demonstrates a qualitative similar behavior in the frequency space for the observations and simulations. The wavelet spectra for surface pressure display enhanced spectral energy for periods between 5-10 days (baroclinic scale) and 15-30 days (transient scales) in NP-35 observations, HIRHAM ensemble mean and $\mathrm{f} 12$ simulations. The $2 \mathrm{~m}$ air temperature spectra show peaks between 5-20 days and the $10 \mathrm{~m}$ wind spectra between 10-20 days. The general agreement of spectral peaks on both baroclinic and transient scales in the observations and simulations suggests that the variations of surface pressure, $2 \mathrm{~m}$ air temperature and $10 \mathrm{~m}$ wind conditions are satisfactorily reproduced by the model, although the temporal details especially for $10 \mathrm{~m}$ wind differ. The detected variance peaks are associated with baroclinic pressure systems and transient systems and larger planetary scale variations, similar to those described by Jaiser et al. (2012).

Figure 5 displays the pan-Arctic distribution of mean sea level pressure for the 5 months November 2007-March 2008 in the operational ECMWF analysis, and the
ACPD

$14,11855-11893,2014$

Atmospheric winter conditions 2007/08

M. Mielke et al.

Title Page

Abstract

Introduction

Conclusions

References

Tables

Figures

14

$\Delta$

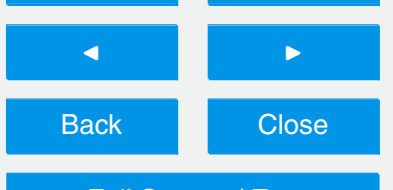

Full Screen / Esc

Printer-friendly Version

Interactive Discussion 
differences to the HIRHAM f12, HIRHAM ens, HIRHAM clima and HIRHAM b10 simulations. The position of NP-35 is indicated by filled black points. The large-scale atmospheric patterns with the Icelandic low and a high pressure bridge from Siberia to Alaska during winter are well reproduced by all different model setups. In February 5 and March the agreement of the RCM simulations with ECMWF analysis is very high, whereas in November and December the high pressure bridge in the simulations over the Chukchi Sea is too weak and in January too strong. The impact of the changed stability functions in the HIRHAM b10 run from November to January is clearly visible.

\subsection{Vertical profiles of temperature, wind and humidity}

10 Monthly mean vertical profiles of observed and simulated air temperature, relative humidity and wind speed between the surface and $2000 \mathrm{~m}$ and the HIRHAM ensemble standard deviations are displayed in Fig. 6. The vertical temperature structure and surface inversions are captured in the model simulations with different biases for the investigated months (biases in the order of $\pm 4 \mathrm{~K}$ ). The agreement for November, December, February and March is acceptable. The January temperature profile of the HIRHAM ens simulations shows a difference of around $5 \mathrm{~K}$, connected with a too strong simulated high pressure system in HIRHAM compared to the ECMWF operational analyses north of the NP-35 position (Fig. 5). The surface inversion strength in the lower troposphere differs significantly. In November and March the simulations 20 of HIRHAM ens show too weak vertical mixing, whereas in December, January and February the vertical exchange is too strong, resulting in vertical model profiles with too weak temperature gradients. The too excessive vertical mixing of heat in HIRHAM is in agreement with results of Andreas (1987) and Andreas et al. (2005). On the basis of eddy-covariance measurements they showed that the roughness lengths with

\section{ACPD}

$14,11855-11893,2014$

Atmospheric winter conditions 2007/08

M. Mielke et al.

Title Page

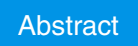

Introduction

Conclusions

References

Tables

Figures

14

I

4

Back

$>$

Close

Full Screen / Esc

Printer-friendly Version

Interactive Discussion yet taken into account by current climate models. Assuming an unrealistic value for the roughness length an excessive vertical mixing of heat can occur, which is a common problem for many models. The roughness length additionally depends on the surface 
conditions, which in the applied model are only poorly represented at the sea icesnow-atmosphere interface.

The forecast mode reproduces the vertical temperature profile much better than the climate mode. The top of the surface temperature inversions appears between 600$5800 \mathrm{~m}$ altitude in agreement with the estimates of Vihma et al. (2008) for spring and summer. For relative humidity, the simulated top of surface inversions occurs at lower altitudes $(200 \mathrm{~m})$. The modeled wind speed near the surface is almost identical to the observed. In the vertical, local maxima of wind speed occur as low-level jets between 200-400 m height, which are only poorly simulated by the models. Changed stability 10 functions in the HIRHAM b10 simulations, represented by the blue curves in Fig. 2, have a clear impact on the vertical atmospheric structure.

Based on Fig. 6, the largest across-ensemble scatter, described by the \pm standard deviations in the HIRHAM ens simulations, occurs for wind speed and relative humidity throughout all months. The weakest temperature scatter appears in November and the strongest in February and March, when the lateral boundary forcing through large-scale atmospheric waves is dominating, as pointed out by Rinke et al. (2004). This shows that the internally generated atmospheric variability depends on the season being larger in winter months.

The overall statistics of the temperature bias have been computed near the surface 20 (Fig. 7a), at $850 \mathrm{hPa}$ (Fig. 7b) and in the free troposphere at $500 \mathrm{hPa}$ (Fig. 7c) for the climate and forecast mode, the operational ECMWF analysis and the HIRHAM b10 run. The strongest biases of $\pm 5 \mathrm{~K}$ occur close to the surface and are smaller in the forecast mode. In $85 \%$ of the cases HIRHAM f12 shows positive or negative biases lower than $1 \mathrm{~K}$, which is even better than for ECMWF $(78 \%)$. At $850 \mathrm{hPa}$ the bias declines for all model simulations, and in the free troposphere at $500 \mathrm{hPa}$ the model biases in the forecast run HIRHAM f12 and ECMWF are much less pronounced and reach $\pm 3 \mathrm{~K}$. The HIRHAM b10 bias is very similar to that of the ensemble run.

ACPD

$14,11855-11893,2014$

Atmospheric winter conditions 2007/08

M. Mielke et al.

Title Page

Abstract Introduction

Conclusions References

Tables Figures

14

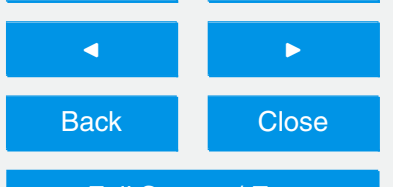

Full Screen / Esc

Printer-friendly Version

Interactive Discussion 


\subsection{Low-level inversions}

An essential feature of stable ABL conditions is the occurrence of surface inversions. Figure $8 \mathrm{a}$ displays the altitude and strength of surface-based inversions, while Fig. 8b shows those characteristics for elevated inversions, all for November 2007-March 2008

5 based on NP-35 measurements. A preference of near-surface and elevated inversions up to $500 \mathrm{~m}$ is obvious.

Figure 9 compares the frequency of occurrence of temperature surface inversions heights and strength for November 2007-March 2008 from the measurements and the HIRHAM simulations. Compared to the NP-35 observations, the model simulates surface-based inversions too often. Whereas the total number of observed surfacebased inversions derived from 12 hourly radio sounding data is 171, HIRHAM ens simulates 53 more and HIRHAM f12 indicates 48 more than observed. The observations exhibit very strong temperature inversions near the surface, whereas the simulated inversions occur frequently between the surface and $415 \mathrm{~m}$ at too high levels. The ob15 served inversion strength is partly reproduced by the simulations and illustrate that most inversions have strengths of $1-7 \mathrm{~K} / 100 \mathrm{~m}$.

The reason for too many modeled surface-based inversions in HIRHAM with concurrent too strong vertical mixing of heat is not clear, but could be connected with the poorly simulated cloud-ABL feedbacks. RCMs have considerable difficulties in simulating Arctic clouds correctly as pointed out by Wyser et al. (2008). The HIRHAM simulations show a minimum in cloud water (liquid plus ice) at near-surface atmospheric levels and a maximum near $200 \mathrm{~m}$ as evaluated by Tjernström et al. (2008). The model difficulties in characterizing low thick clouds could be related to the models ability to resolve Arctic inversions. However, temperature inversions below $15 \mathrm{~m}$ as well as above $550 \mathrm{~m}$ altitude occur more frequently in the model. HIRHAM simulates the statistics of surface-based inversions strength better than that of height.

In the $A B L$ temperature inversions are often connected with low-level wind jets. While for the observations 58 low-level jets have been detected, HIRHAM f12 (HIRHAM ens)

Atmospheric winter conditions 2007/08

M. Mielke et al.

Title Page

Abstract Introduction

Conclusions References

Tables Figures

14 $\Delta$

4

Back

Full Screen / Esc

Printer-friendly Version

Interactive Discussion 
simulated only 7 (2). For these cases both HIRHAM ens and HIRHAM f12 underestimate the observed wind speeds between $4 \mathrm{~ms}^{-1}$ (HIRHAM f12) and $8 \mathrm{~ms}^{-1}$ (HIRHAM ens), not explicitly shown here. The simulated vertical wind gradients are too weak and large biases in the vertical wind profiles exist (Fig. 6). The simulated jets are located 5 at the wrong height of around $400 \mathrm{~m}$ compared to $200-300 \mathrm{~m}$ in the observations (not shown).

\subsection{Distinct atmospheric circulation states}

Stramler et al. (2011) detected two different synoptically driven atmospheric circulation states for the winter of the SHEBA year 1997/98. Figure 10 shows the observed and simulated frequency distribution of surface net LW radiation with respect to the NP-35 drift. The NP-35 extended winter observations indicate two different radiative-turbulent states below and above $30 \mathrm{Wm}^{-2}$. Whereas the HIRHAM f12 simulation does not show the two distinct atmospheric states, the HIRHAM clima and HIRHAM b10 simulations qualitatively indicate both states. Figure 10 demonstrates the importance of applying 5 accurate initial conditions for reproducing the two differing states. HIRHAM clima and HIRHAM b10 use the most realistic initial conditions and are therefore able to reproduce the distinct states qualitatively, whereas HIRHAM ens with modified initial conditions fails.

Figure 11 shows the associated different circulation states at the mean sea level, 850

and $500 \mathrm{hPa}$ as a composite for November 2007 until March 2008 for the two different radiative-turbulent states with net $\mathrm{LW}$ radiation below and above $30 \mathrm{Wm}^{-2}$ based on HIRHAM clima and HIRHAM b10 simulations. Figure 11 indicates a southward extension of the high pressure region for the one regime (net $\mathrm{LW}$ radiation above $30 \mathrm{Wm}^{-2}$ ) and a more northward extension of low pressure for the other regime (net LW values 25 below $30 \mathrm{Wm}^{-2}$ ) over the central Arctic Ocean. The difference plots (difference between the two states) indicate an enhanced Arctic high pressure over the center of the Arctic Ocean and in the vicinity of NP-35 position for surface net LW radiation values above $30 \mathrm{Wm}^{-2}$. The higher pressure regime over the Arctic Ocean is associated 11868

\section{ACPD}

$14,11855-11893,2014$

Atmospheric winter conditions 2007/08

M. Mielke et al.

Title Page

Abstract Introduction

Conclusions References

Tables Figures

14 $\Delta$

4

Back

Full Screen / Esc

Printer-friendly Version

Interactive Discussion 
with less clouds, reduced downward LW radiation and therefore higher radiative loss at the surface and colder temperatures. The other LW-driven (associated with values less than $30 \mathrm{Wm}^{-2}$ ) circulation state over the Arctic Ocean with reduced pressure is associated with more clouds, enhanced downward LW radiation and smaller radiative 5 cooling at the surface.

Over the Beaufort and Barents Seas the difference plots indicates different patterns with lower pressure states for surface net LW radiation values above $30 \mathrm{Wm}^{-2}$. Unfortunately, the poor NP-35 cloud observations and the HIRHAM deficits with respect to low cloud simulations do not allow quantitative estimations as in Stramler et al. (2011). 10 The atmospheric circulation state changes with height and contains strong barotropic and baroclinic components. The impact of a changed stability function is clearly visible, so that the enhanced vertical stability in the HIRHAM b10 simulation leads to strong changes in the baroclinic structure between the surface and $850 \mathrm{hPa}$. The relatively cold high pressure conditions resemble the radiative-driven clear state described by 15 Stramler et al. (2011), and the reduced high pressure conditions with more clouds are similar to their cloudy state connected with stronger baroclinic pressure systems.

The two differing radiative circulation states could be associated with changed interaction between radiative and turbulence processes. Figure 12 displays the ratio between the surface heat fluxes and the $10 \mathrm{~m}$ wind SHF/ $u$ as a function of $\Delta T$ derived from the bulk parameterization of Zilitinkevich (1970) for both atmospheric circulation states from November 2007 until March 2008. According to the bulk-flux formula, the SHF is proportional to both the $10 \mathrm{~m}$ wind speed $u$ and the air-surface temperature difference $\left(T_{\text {air }}-T_{\text {srfc }} ; \Delta T\right)$ in such a way, that SHF $=-\rho c_{\mathrm{p}} u C_{\mathrm{h}}\left(T_{\text {air }}-T_{\text {srfc }}\right)$. Here, $\rho$ is the air density, $C_{\mathrm{p}}$ is the specific heat capacity at constant pressure, and $C_{\mathrm{h}}$ is the heat transfer coefficient. Turbulent mixing is determined by the thermal stratification and the vertical wind shear.

For the two different circulation states connected with two distinct radiative equilibria the interaction of subgrid-scale turbulence and high or low pressure systems differ considerably. The high pressure state with surface net LW radiation values above
ACPD

$14,11855-11893,2014$

Atmospheric winter conditions 2007/08

M. Mielke et al.

Title Page

Abstract

Introduction

Conclusions

References

Tables

Figures

14

$\Delta$

4

Back

$\triangleright$

Close

Full Screen / Esc

Printer-friendly Version

Interactive Discussion 
$30 \mathrm{Wm}^{-2}$ is connected with more frequent stable conditions and reduced vertical turbulent exchange. For this state a stronger nonlinearity is visible in the scatter plots' tails of Fig. 12 that might be associated with intermittent turbulence under more stable conditions. For weaker high pressure conditions connected with surface net LW radiation 5 values below $30 \mathrm{Wm}^{-2}$ the scatter plots indicate a more linear behavior most likely due to enhanced turbulent exchange and cloud formation.

Following the nonlinearity of the subgrid-scale coupling with atmospheric meso-scale and baroclinic systems, the right amount of turbulent mixing, which allows the appropriate representation of surface values and the atmospheric profile in a vertical column 10 connected to horizontal atmospheric advection is a very delicate issue. Thus, the parameterization impact differs depending on the synoptical situation. Furthermore, the results of the whole ensemble show that the same parameterization does not produce the best results under different lateral boundary conditions and for different internally generated variability.

15 Mokhov et al. (2007) analyzed polar meso-scale cyclones with diameters from 50 to $400 \mathrm{~km}$ over the North European Basin for the period 1981-1995 and showed that their time scales are in the order of 1-3 days. Figure 13 displays this synoptic-scale variability of band-pass filtered time series of sea level pressure on time scales from 1-3 days from November 2007 until March 2008 for the ECMWF analyses as well as 20 the HIRHAM clima and HIRHAM b10 runs. The analyses and the two simulations all show quite similar storm tracks over the Atlantic with differing regional details in the Barents and Beaufort Seas.

The changed synoptic systems influence the baroclinic time scales up to 10 days as displayed in Fig. 14 with strongest changes over the Arctic Ocean basin from November 25 until February. In November and December the baroclinic processes change along the Siberian coast. In February the strongest variability occurs in the Norwegian and Barents Seas. The enhanced vertical stability in HIRHAM b10 reduces the baroclinicscale variability over the Barents and Kara Seas.

\section{ACPD}

$14,11855-11893,2014$

Atmospheric winter conditions 2007/08

M. Mielke et al.

Title Page

Abstract

Introduction

Conclusions

References

Tables

Figures

14

$\Delta$

4

Back

Close

Full Screen / Esc

Printer-friendly Version

Interactive Discussion 
Figure 15 displays the planetary-scale variability of mean sea level pressure and $500 \mathrm{hPa}$ geopotential fields on time scales between 10-20 days. By comparing Figs. 14 and $15 \mathrm{a}$ a pronounced baroclinic-barotropic interaction in November over the Arctic Ocean is visible. The variability of the $500 \mathrm{hPa}$ geopotential height fields in Fig. 15b 5 indicates a barotropic signature for November and December and larger scale variability patterns dominated by baroclinic-barotropic interactions in February. The use of increased vertical stability in the model simulation leads to diminished planetary-scale variability over the Arctic Ocean.

\section{Summary and conclusions}

10 Atmospheric measurements on the drifting Arctic sea ice station "North Pole-35" crossing the Eastern part of the Arctic Ocean during winter 2007/2008 have been presented and compared with RCM simulations in the forecast and the climate mode with sensitivity runs carried out with changed ABL stability functions. The observed near-surface temperature, mean sea level pressure and the vertical profiles of temperature and wind 15 are satisfactorily reproduced by the simulations. Significant temperature differences between observations and the simulations occur near the surface due to overestimated vertical mixing of heat in the stable $A B L$. The observations show temperature inversions between the surface and ca. $400 \mathrm{~m}$ height, whereas the simulated elevated inversions occur at too high levels above $400 \mathrm{~m}$ and the frequency of surface inversions is overestimated. The applied RCM fails in reproducing the occurrence of low-level jets, which are observed between 200-400 m height, because it underestimates the wind speed and its sharp vertical gradients. LW radiative and cloud simulation errors are obvious for winter conditions in HIRHAM, which influence vertical cloud-ABL feedbacks. HIRHAM simulates too many elevated inversions compared to the NP-35 data, which could be

The observations indicate two different radiative-turbulent circulation states with surface net $\mathrm{LW}$ radiation higher or lower than $30 \mathrm{Wm}^{-2}$. These states are reproduced by

\section{ACPD}

$14,11855-11893,2014$

Atmospheric winter conditions 2007/08

M. Mielke et al.

Title Page
Abstract

Conclusions

Tables

14

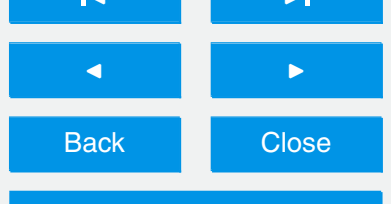

Full Screen / Esc
Interactive Discussion 
the HIRHAM simulations with a weakened high pressure dominated state for net LW radiation values below $30 \mathrm{Wm}^{-2}$ and an enhanced high pressure dominated state for higher net LW radiative fluxes. The importance of the right initial conditions in reproducing the distinct circulation states was shown. The associated atmospheric circulation 5 structures change from the surface to $500 \mathrm{hPa}$ and contain a strong baroclinic component, which depends on the used ABL stability function. This feedback changes the synoptical cyclone tracks and the large-scale planetary wave patterns during winter through baroclinic-barotropic interactions. The role of internal dynamics due to different initial conditions on the temporal development of atmospheric surface variables and vertical profiles of temperature, wind and relative humidity has been quantified in ensemble simulations. The scatter due to internally generated variability in the large Arctic integration domain is high and adds to the differences between members of an ensemble of simulations, which results from changes in model parameters as pointed out by Rinke and Dethloff (2000) and Laprise et al. (2008).

The quality of any climate model (e.g. Handorf and Dethloff, 2012) therefore strongly depends on the used subgrid-scale parameterizations that describe the complex smallscale interacting processes between sea ice, snow, clouds, stable $A B L$ turbulence and radiation. These schemes interact differently depending on the synoptical conditions in a two-way mode with baroclinic and large-scale circulation patterns.

The only way to better evaluate the performance of models in the Arctic is to confront the models with more high-quality datasets covering the vertical and horizontal structure of the atmosphere. Our scientific understanding of main Arctic climate processes is mainly limited by the lack of observations over the Arctic Ocean due to logistical and practical reasons. Multi-year, detailed and comprehensive measurements covering an the atmosphere, in the central Arctic Basin, would be needed to provide an improved process-level understanding of the Arctic climate system, which is necessary for improved modelling of Arctic climate and weather conditions, and for the prediction of future changes in the Arctic.
ACPD

14, 11855-11893, 2014

Atmospheric winter conditions 2007/08

M. Mielke et al.

Title Page

Abstract

Introduction

Conclusions

References

Tables

Figures

14

$\Delta$

4

Back

$\triangleright$

Close

Full Screen / Esc

Printer-friendly Version

Interactive Discussion 
Acknowledgements. J. Graeser thanks the Russian team for their hospitality during his overwintering on NP-35. We thank I. Hebestadt and S. Erxleben for running the HIRHAM model and preparing the figures.

\section{References}

5 Andreas, E. L.: A theory for the scalar roughness and the scalar transfer coefficients over snow and sea ice, Bound.-Lay. Meteorol., 38, 159-184, 1987.

Andreas, E. L., Jordan, R. E., and Makshtas, A. P.: Parameterizing turbulent exchange over sea ice: the Ice Station Weddell results, Bound.-Lay. Meteorol., 114, 439-460, 2005.

Atlaskin, E. and Vihma, T.: Evaluation of NWP results for wintertime nocturnal boundary10 layer temperatures over Europe and Finland, Q. J. Roy. Meteor. Soc., 138, 1440-1451, doi:10.1002/qj.1885, 2012.

Brinkop, S. and Roeckner, E.: Sensitivity of a general circulation model to parameterizations of cloud-turbulence interactions in the atmospheric boundary layer, Tellus A, 47, 197-220, 1995.

15 Cassano, J. J., Higgins, M. E., and Seefeldt, M. W.: Performance of the weather research and forecasting model for month-long pan-arctic simulations, Mon. Weather Rev., 139, 34693488, 2011.

Dethloff, K., Rinke, A., Lehmann, R., Christensen, J. H., Botzet, M., and Machenhauer, B.: Regional climate model of the Arctic atmosphere, J. Geophys. Res., 101, 23401-23422, 201996.

Gascard, J.-C., Festy, J., le Goff, H., Weber, M., Bruemmer, B., Offermann, M., Doble, M., Wadhams, P., Forsberg, R., Hanson, S., Skourup, H., Gerland, S., Nicolaus, M., Metaxian, J.-P., Grangeon, J., Haapala, J., Rinne, E., Haas, C., Wegener, A., Heygster, G., Jakobson, E., Palo, T., Wilkinson, J., Kaleschke, L., Claffey, K., Elder, B., and Bottenheim, J.: Exploring

25 Arctic transpolar drift during dramatic sea ice retreat, EOS, 89, 21-23, 2008.

Grachev, A. A., Andreas, E. L., Fairall, C. W., Guest, P. S., and Persson, P. O. G.: SHEBA fluxprofile relationships in the stable atmospheric boundary layer, Bound.-Lay. Meteorol., 124, 315-333, 2007.

Atmospheric winter conditions 2007/08

M. Mielke et al.

Title Page

Abstract Introduction

Conclusions References

Tables

Figures

14

$>1$

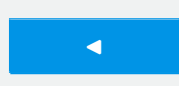

Back

$>$

Close

Full Screen / Esc

Printer-friendly Version

Interactive Discussion 
Handorf, D. and Dethloff, K.: How well do state-of-the-art Atmosphere-Ocean General Circulation Models reproduce atmospheric teleconnection patterns?, Tellus A, 64, 19777, doi:10.3402/tellusa.v64i0.19777, 2012.

Jaiser, R., Dethloff, K., Handorf, D., Rinke, A., and Cohen, J.: Impact of sea ice cover 5 changes on the Northern Hemisphere atmospheric winter circulation, Tellus, 64, 11595, doi:10.3402/tellusa.v64i0.11595, 2012.

Klaus, D., Dorn, W., Dethloff, K., Rinke, A., and Mielke, M.: Evaluation of two cloud parameterizations and their possible adaptation to Arctic climate conditions, Atmosphere, 3, 419-450, doi:10.3390/atmos3030419, 2012.

10 Laprise, R., de Elia, R., Caya, D., Biner, S., Lucas-Picher, P., Diaconescu, E., Leduc, M., Alexandru, A., and Separovic, L.: Challenging some tenets of Regional Climate Modelling, Meteorol. Atmos. Phys., 100, 3-22, doi:10.1007/s00703-008-0292-9, 2008.

Louis, J. F.: A parametric model of vertical eddy fluxes in the atmosphere, Bound.-Lay. Meteorol., 17, 187-202, 1979.

Mokhov, I. I., Akperov, M. G., Lagun, V. E., and Lutsenko, E. I.: Intense arctic mesocyclones, Atmospheric and Oceanic Physics, 43, 259-265, 2007.

Morcrette, J.-J., Smith, L., and Fouquart, Y.: Pressure and temperature dependence of the absorption in longwave radiation parameterizations, Beitr. Phys. Atmos., 59, 455-469, 1986.

Roeckner, E., Arpe, K., Bengtsson, L., Christoph, M., Claussen, M., Dümenil, L., Esch, M., Giorgetta, M., Schlese, U., and Schulzweida, U.: The atmospheric general circulation model ECHAM-4: model description and simulation of present-day climate, MPI Rep., 218, Max Planck Inst. for Meteorol., Hamburg, Germany, 1996.

Rinke, A. and Dethloff, K.: On the sensitivity of a regional Arctic climate model to initial and boundary conditions, Clim. Res., 14, 101-113, 2000.

Rinke, A., Marbaix, P., and Dethloff, K.: Internal variability in Arctic regional climate simulations: case study for the SHEBA year, Clim. Res., 27, 197-209, 2004.

Rinke, A., Dethloff, K., Cassano, J. J., Christensen, J. H., Curry, J. A., Du, P., Girard, E., Haugen, J.-E., Jacob, D., Jones, C. G., Koltzow, M., Laprise, R., Lynch, A. H., Pfeifer, S., Serreze, M. C., Shaw, M. J., Tjernström, M., Wyser, K., and Zagar, M.: Evaluation of an ensemDynam., 26, 459-472, doi:10.1007/s00382-005-0095-3, 2006.

\section{ACPD}

$14,11855-11893,2014$

Atmospheric winter conditions 2007/08

M. Mielke et al.

Title Page

Abstract Introduction

Conclusions

References

Tables

Figures

14

DI

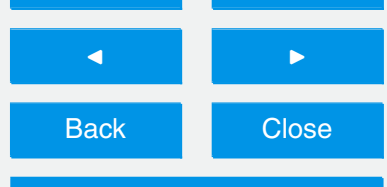

Full Screen / Esc

Printer-friendly Version

Interactive Discussion 
Rinke, A., Melsheimer, C., Dethloff, K., and Heygster, G.: Arctic total water vapour: comparison of regional climate model simulations, and simulated decadal trends, J. Hydrometeorol., 10, 113-129, 2009.

Rinke, A., Yongfeng, M., Lingen, B., Yufei, X., Dethloff, K., Persson, P. O. G., Luepkes, C., and Cunde, X.: Evaluation of atmospheric boundary layer-surface process relationships in a regional climate model along an East Antarctic traverse, J. Geophys. Res., 117, D09121, doi:10.1029/2011JD016441, 2012.

Stramler, K., Del Genio, A. D., and Rossow, W. B.: Synoptically driven Arctic winter states, J. Climate, 24, 1747-1762, doi:10.1175/2010JCLI3817.1, 2011.

10 Tastula, E.-M., Vinma, T., and Andreas, E. L.: Evaluation of polar WRF from modeling the atmospheric boundary layer over Antarctic sea ice in autumn and winter, Mon. Weather Rev., 140, 3919-3935, doi:10.1175/MWR-D-12-00016.1, 2012.

Tjernström, M., Zagar, M., Svensson, G., Cassano, J., Pfeifer, S., Rinke, A., Wyser, K., Dethloff, K., Jones, C., and Semmler, T.: Modeling the Arctic boundary layer: an evaluation of six ARC-MIP regional-scale models with data from the SHEBA project, Bound.-Lay. Meteorol., 117, 337381, doi:10.1007/s10546-004-7954-z, 2005.

Tjernström, M., Sedlar, J., and Shupe, M.: How well do regional climate models reproduce radiation and clouds in the Arctic? An evaluation of ARCMIP simulations, J. Appl. Meteorol.Clim., 47, 2405-2422, 2008.

20 Torrence, C. and Campo, G. P.: A practical guide to wavelet analysis, B. Am. Meteorol. Soc., 79, 61-78, 1998.

Vihma, T., Jaagus, J., Jakobson, E., and Palo, T.: Meteorological conditions in the Arctic Ocean in spring and summer 2007 as recorded on the drifting ice station Tara, Geophys. Res. Lett., 35, L18706, doi:10.1029/2008GL034681, 2008.

Wyser, K., Jones, C. G., Du, P., Girard, E., Willen, U., Cassano, J., Christensen, J. H., Curry, J. A., Dethloff, K., Haugen, J.-E., Jacob, D., Køltzow, M., Laprise, R., Lynch, A., Pfeifer, S., Rinke, A., Serreze, M., Shaw, M. J., Tjernström, M., and Zagar, M.: An evaluation of Arctic cloud and radiation processes during the SHEBA year: simulation results from 8 Arctic Regional Climate Models, Clim. Dynam., 30, 203-223, doi:10.1007/s00382-007-0286-1, 2008.

hang, Y. and Seidel, D. J.: Challenges in estimating trends in Arctic surface-based inversions from radiosonde data, Geophys. Res. Lett., 38, L17806, doi:10.1029/2011GL048728, 2011.

Zilitinkevich, S. S.: The Dynamics of the Atmospheric Boundary Layer, Gidrometizdat, Leningrad, 292 pp., 1970.

14, 11855-11893, 2014

Atmospheric winter conditions 2007/08

M. Mielke et al.

Title Page

Abstract

Introduction

Conclusions

References

Tables

Figures

14

$\Delta$

4

Back

$\triangleright$

Close

Full Screen / Esc

Printer-friendly Version

Interactive Discussion 
ACPD

14, 11855-11893, 2014

Atmospheric winter conditions 2007/08

M. Mielke et al.

Table 1. Measuring range and accuracy of atmospheric quantities measured on NP-35.

\begin{tabular}{lrr}
\hline Parameter & $\begin{array}{r}\text { Range of } \\
\text { measurements }\end{array}$ & Accuracy \\
\hline Wind speed $\left(\mathrm{ms}^{-1}\right)$ & $0-75$ & $\pm(0.5+0.05 \mathrm{~V})$ \\
Wind direction $(\mathrm{deg})$ & $0-360$ & \pm 5 \\
Surface pressure $(\mathrm{hPa})$ & $3-1100$ & \pm 0.5 \\
Air temperature $\left({ }^{\circ} \mathrm{C}\right)$ & $-50-60$ & \pm 0.2 \\
Relative humidity $(\%)$ & $0-100$ & \pm 3 \\
Surface temperature $\left({ }^{\circ} \mathrm{C}\right)$ & $-50-60$ & \pm 0.2 \\
Downward \& upward short- & $0-4000$ & \pm 10 \\
and long-wave radiation $\left(\mathrm{Wm}^{-2}\right)$ & & \\
\hline
\end{tabular}

Title Page

Abstract

Introduction

Conclusions

References

Tables

Figures

14

$\rightarrow 1$

4

$\checkmark$

$>$

Back

Close

Full Screen / Esc

Printer-friendly Version

Interactive Discussion

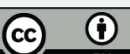




\section{ACPD}

\section{$14,11855-11893,2014$}

Atmospheric winter conditions 2007/08

M. Mielke et al.

Table 2. Measured and simulated atmospheric parameters, their root mean square errors and the correlation between observations and simulations at NP-35 for the time period November 2007-March 2008 based on 6 hourly data.

\begin{tabular}{lrrr|rrrr}
\hline & & Mean values & Root mean square errors & $\begin{array}{c}\text { Correlation } \\
\text { between } \\
\text { observation } \\
\text { simulation }\end{array}$ \\
& & & & & & &
\end{tabular}

Title Page

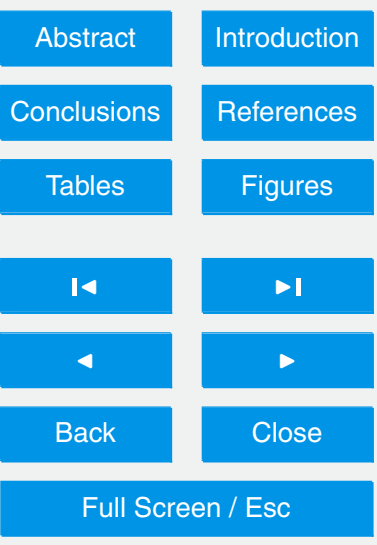

Printer-friendly Version

Interactive Discussion 


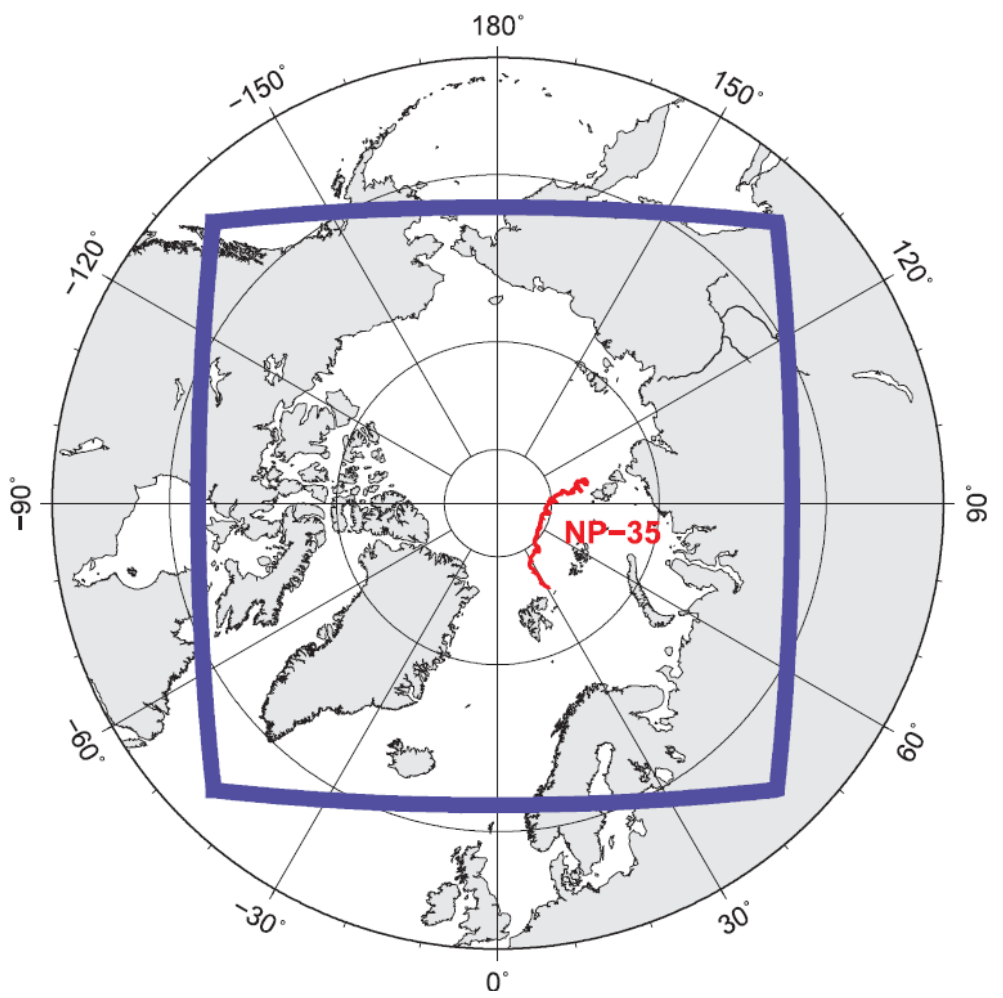

Fig. 1. The pan-Arctic integration domain of the atmospheric regional climate model HIRHAM and the trajectory of NP-35 from October 2007 until July 2008.

\section{ACPD}

\section{$14,11855-11893,2014$}

\section{Atmospheric winter}

conditions 2007/08

M. Mielke et al.

Title Page

Abstract

Conclusions

Tables

14

4

Back

Full Screen / Esc

Printer-friendly Version

Interactive Discussion 


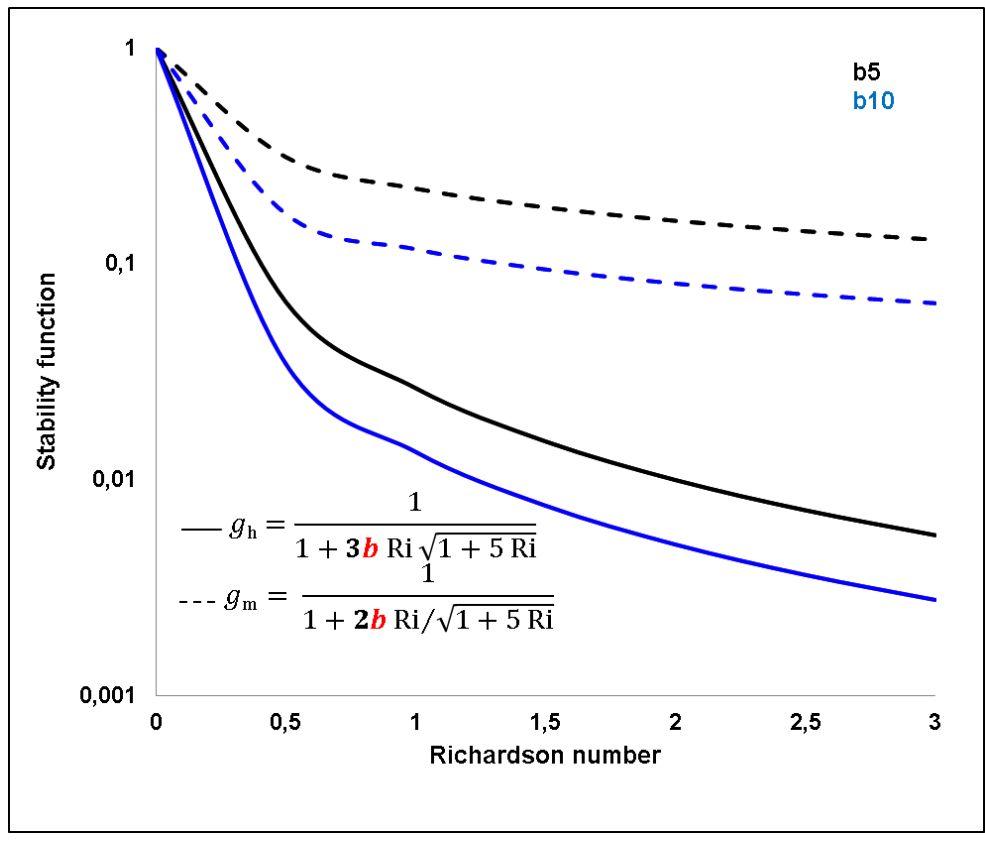

Fig. 2. The stability functions of heat $\left(g_{h}\right.$, solid lines) and momentum $\left(g_{m}\right.$, dashed lines) with changing $b$ parameter (default $b=5$ ) and $b=10$ over the Richardson number used in the sensitivity experiment for the stable ABL.

ACPD

$14,11855-11893,2014$

Atmospheric winter conditions 2007/08

M. Mielke et al.

Title Page

Abstract

Conclusions

Tables

14

4

Back

Introduction

References

Figures

$>$ I

$>$

Close

Full Screen / Esc

Printer-friendly Version

Interactive Discussion 


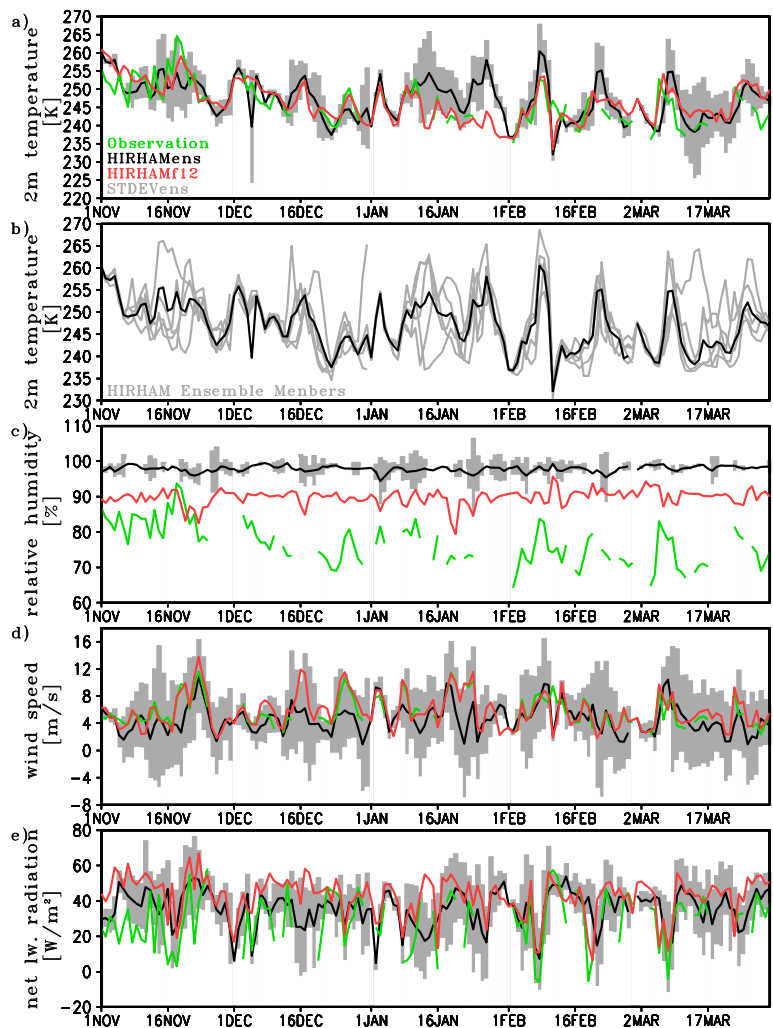

\section{ACPD}

14, 11855-11893, 2014

Atmospheric winter conditions 2007/08

M. Mielke et al.

Title Page

Abstract

Conclusions

Tables

14

4

Back Introduction

References

Figures

$\rightarrow$

$>$

Close

Full Screen / Esc

Printer-friendly Version

Interactive Discussion

Fig. 3. Daily-mean time series of (a) $2 \mathrm{~m}$ air temperature, (b) $2 \mathrm{~m}$ air temperature HIRHAM ensemble members simulations with HIRHAM ens mean (black) and HIRHAM ens member (grey), (c) $2 \mathrm{~m}$ relative humidity, (d) $10 \mathrm{~m}$ wind speed, (e) surface net LW radiation for November 2007March 2008 at NP-35 location. NP-35 measurements are in green, the according model simulations with HIRHAM ens mean in black, HIRHAM ens members in grey and HIRHAM f12 in red. Standard deviation of HIRHAM ensemble simulations is shown by the grey columns. 

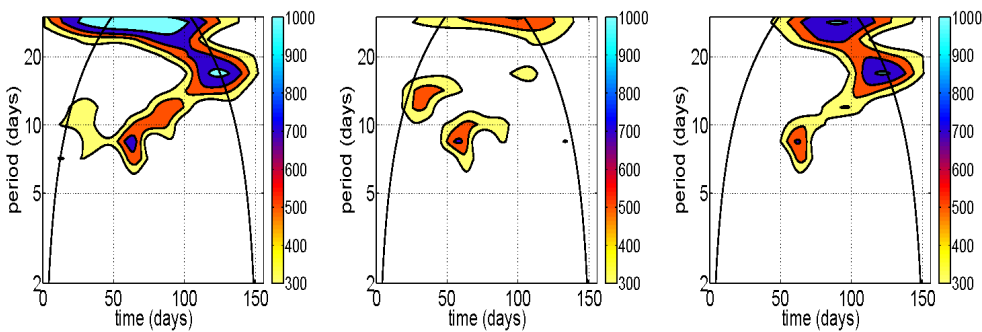

\section{ACPD}

14, 11855-11893, 2014
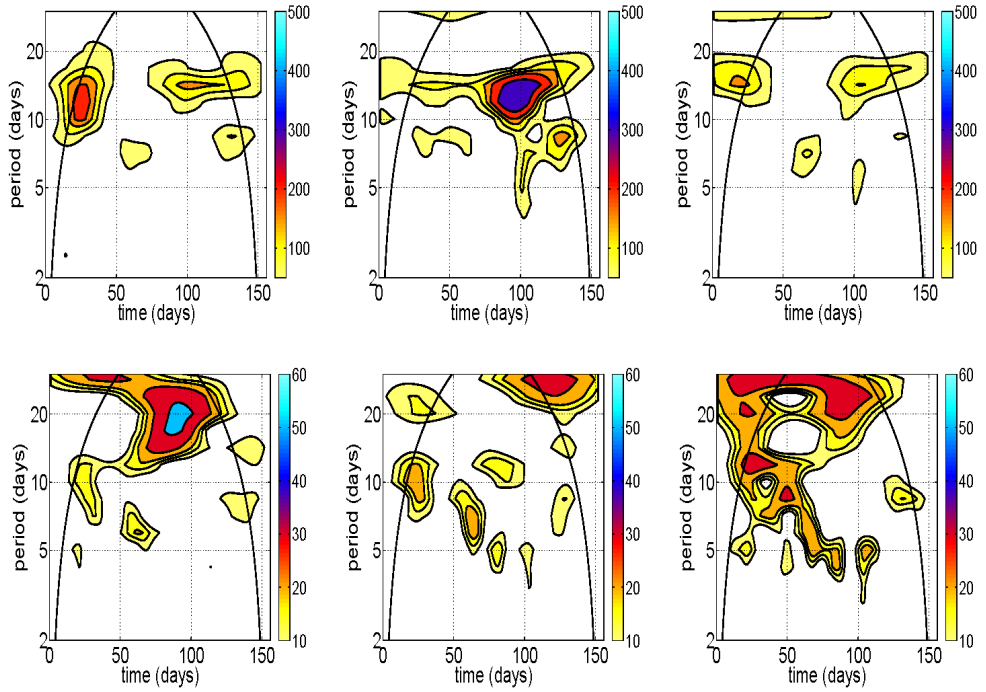

Atmospheric winter conditions 2007/08

M. Mielke et al.

Title Page

Abstract

Conclusions

Tables

14

4

Back Introduction

Figures

$>$ I

$>$

Close

Fig. 4. Wavelet spectra of surface pressure (upper row), $2 \mathrm{~m}$ air temperature (middle row), $10 \mathrm{~m}$ wind speed (lower row) from HIRHAM simulated and NP-35 observed data for November 2007-March 2008. NP-35 data (left column), HIRHAM ens mean (middle column) and f12 simulations (right column). At both ends, black lines separate regions, where edge effects become important.

Interactive Discussion 


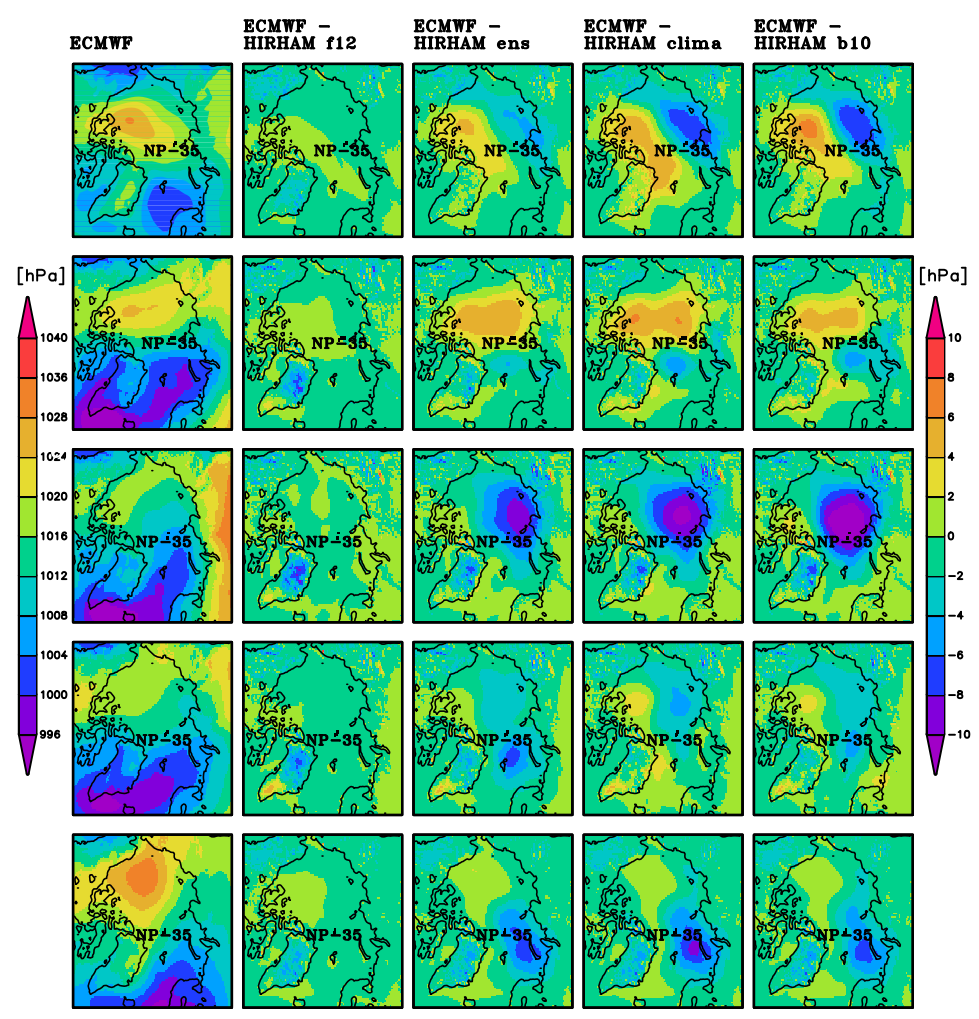

Fig. 5. Pan-Arctic distribution of monthly mean sea level pressure ECMWF (hPa) and differences to various model simulations (hPa) for the period November 2007-March 2008 (left column top to down), (topmost row is for November, second row for December, third for January, fourth for February, lowermost row for March) in the operational "ECMWF analyses minus HIRHAM f12", "ECMWF analyses minus HIRHAM ens", "ECMWF analyses minus HIRHAM clima" and "ECMWF analyses minus HIRHAM b10". The NP-35 position is indicated by the black rectangles.

\section{ACPD}

$14,11855-11893,2014$

Atmospheric winter conditions 2007/08

M. Mielke et al.

Title Page
Abstract

Conclusions

Tables

14

4

Back
Introduction

References

Figures

$\rightarrow$

$>$

Close
Full Screen / Esc

Printer-friendly Version

Interactive Discussion 


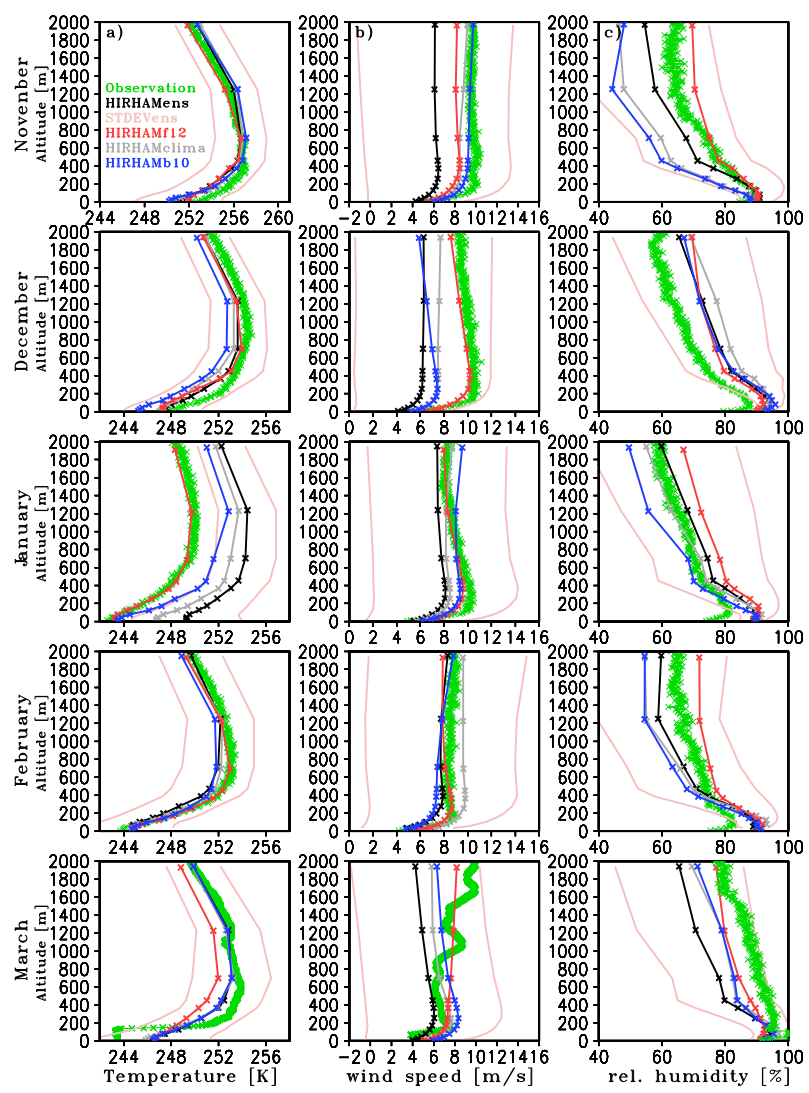

Fig. 6. Monthly mean vertical profiles of temperature (K) (left column), wind speed ( $\left.\mathrm{ms}^{-1}\right)$ (middle column) and relative humidity (\%) (right column) between the surface and $2000 \mathrm{~m}$ altitude, November 2007-March 2008, NP-35 radiosondes (green), HIRHAM ens (black) \pm stdev (pink), HIRHAM clima (grey) and HIRHAM f12 (red). Results of sensitivity study with changed stability functions HIRHAM b10 are in blue.
ACPD

$14,11855-11893,2014$

Atmospheric winter conditions 2007/08

M. Mielke et al.

Title Page
Abstract

Conclusions

Tables

14

4

Back
Introduction

References

Figures

$>1$

$\triangleright$

Close
Full Screen / Esc

Printer-friendly Version

Interactive Discussion 


\section{ACPD}

\section{4, 11855-11893, 2014}

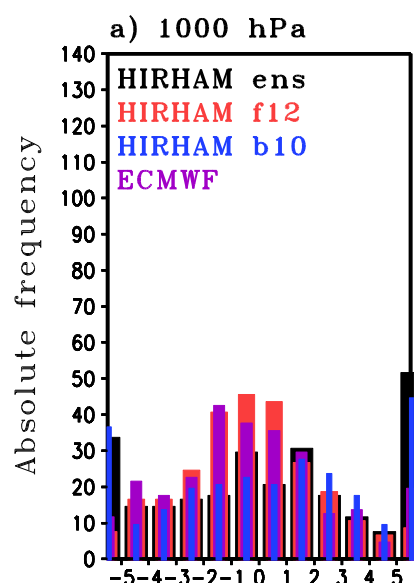

b) $850 \mathrm{hPa}$

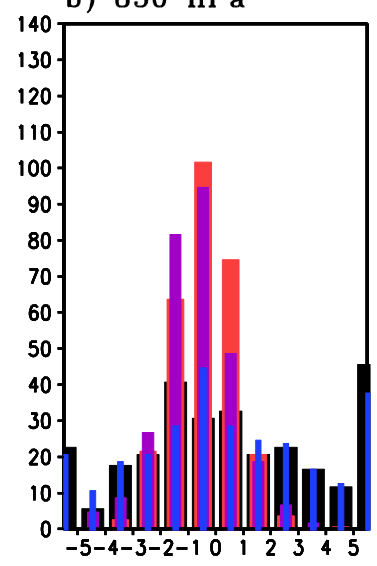

c) $500 \mathrm{hPa}$

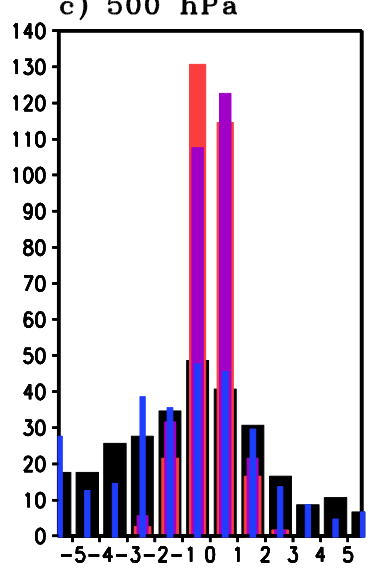

Atmospheric winter conditions 2007/08

M. Mielke et al.

\section{Title Page}

Abstract

Conclusions

Tables

14

4

Back

Full Screen / Esc

Printer-friendly Version

Interactive Discussion 


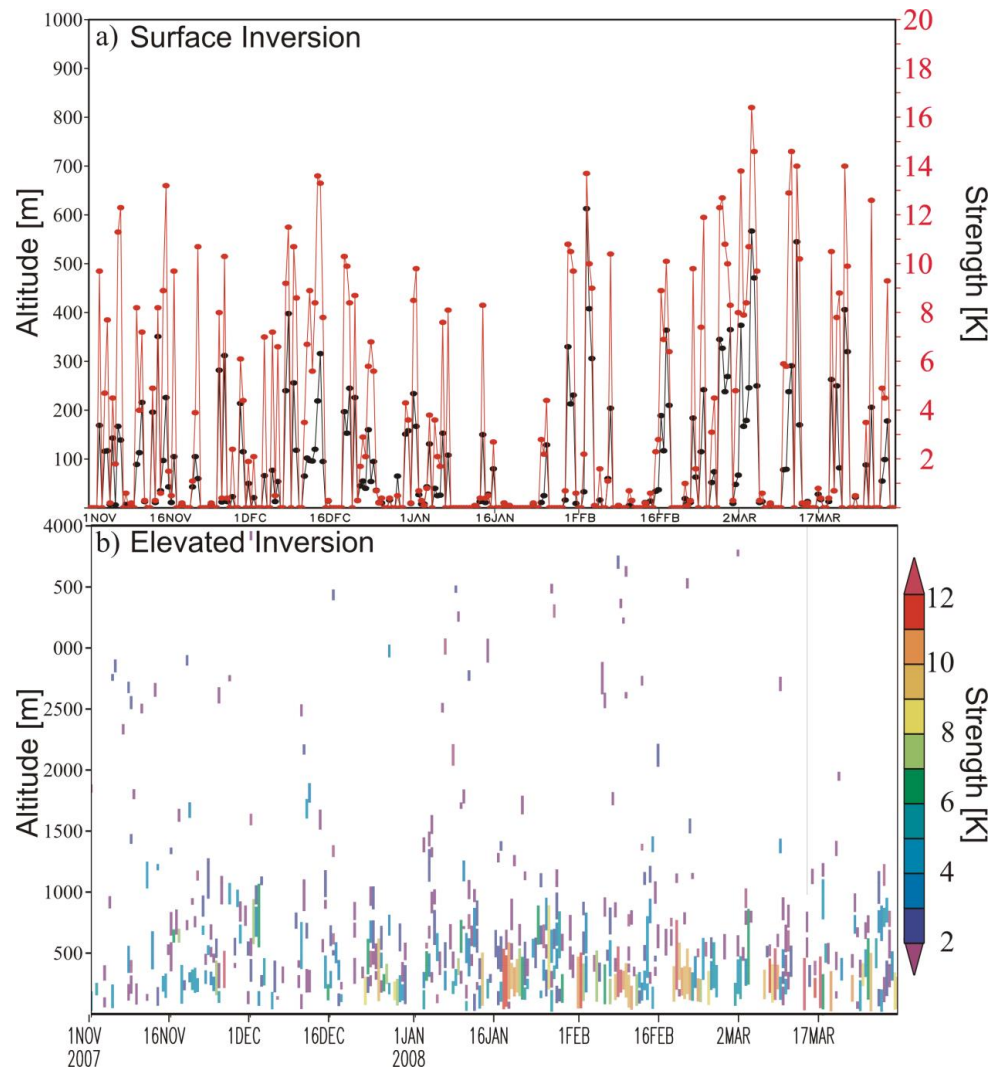

\section{ACPD}

$14,11855-11893,2014$

Atmospheric winter conditions 2007/08

M. Mielke et al.

Title Page

Abstract

Conclusions

Tables

14

4

Back Introduction

References

Figures

$\rightarrow$

$>$

Close

Full Screen / Esc

Printer-friendly Version

Interactive Discussion

Fig. 8. Altitude $(\mathrm{m})$ of surface inversions (black; left $y$ axis) and inversion strength $(\mathrm{K})$ (red; right $y$ axis) (a). Altitude $(\mathrm{m})$ of elevated inversions ( $y$ axis) und inversion strength (K) (color) (b). These results are based on radiosondes carried out on NP-35 with vertical resolution of $1 \mathrm{~s}$ from 1 November 2007 to 31 March 2008. 

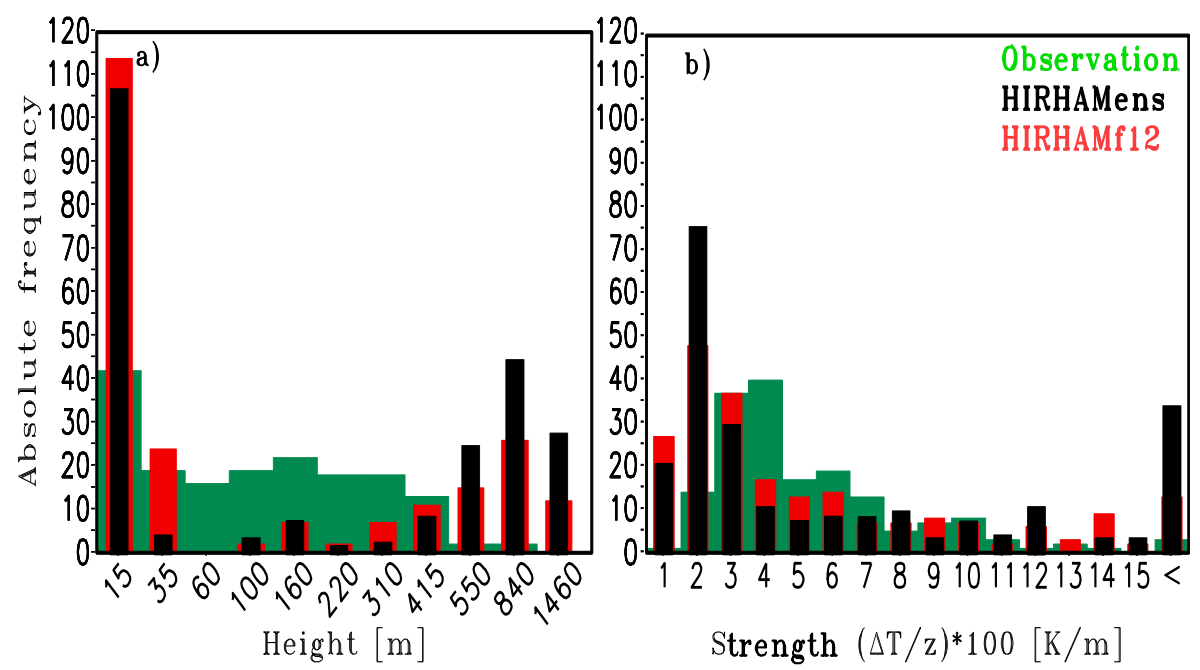

Fig. 9. Frequency of occurrence of surface temperature inversion heights (a), and of inversion strengths (b) for November 2007-March 2008 for NP-35 radiosondes (green) and model simulations HIRHAM ens (black) and HIRHAM f12 (red) at NP-35 location.

\section{ACPD}

$14,11855-11893,2014$

Atmospheric winter conditions 2007/08

M. Mielke et al.

Title Page

Abstract

Conclusions

Tables

14

4

Back Introduction References

Figures

$>1$

$>$

Close

Full Screen / Esc

Printer-friendly Version

Interactive Discussion 


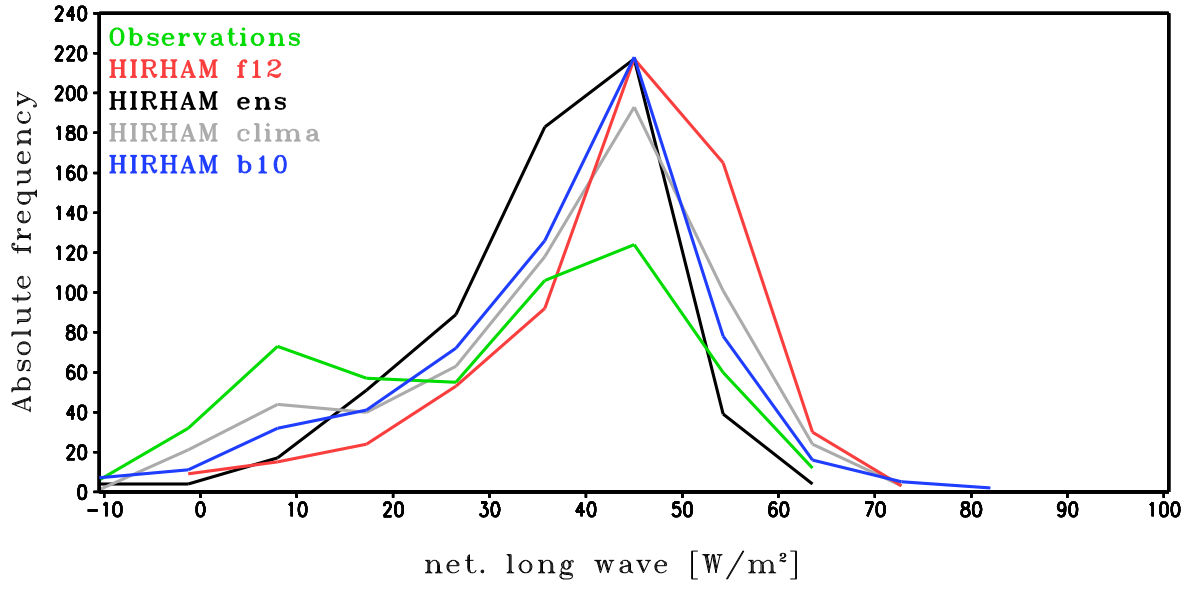

Fig. 10. Frequency of occurrence of surface net LW radiation for NP-35 6 hourly winter (November-March) data from observations (green), HIRHAM f12 (red), HIRHAM ens (black), HIRHAM clima $(b=5)$ (grey) and HIRHAM b10 (blue).

ACPD

$14,11855-11893,2014$

Atmospheric winter conditions 2007/08

M. Mielke et al.

Title Page

Abstract

Conclusions

Tables

14

4

Back Introduction

\section{Figures}

$>1$

$>$

Close

Full Screen / Esc

Printer-friendly Version

Interactive Discussion 


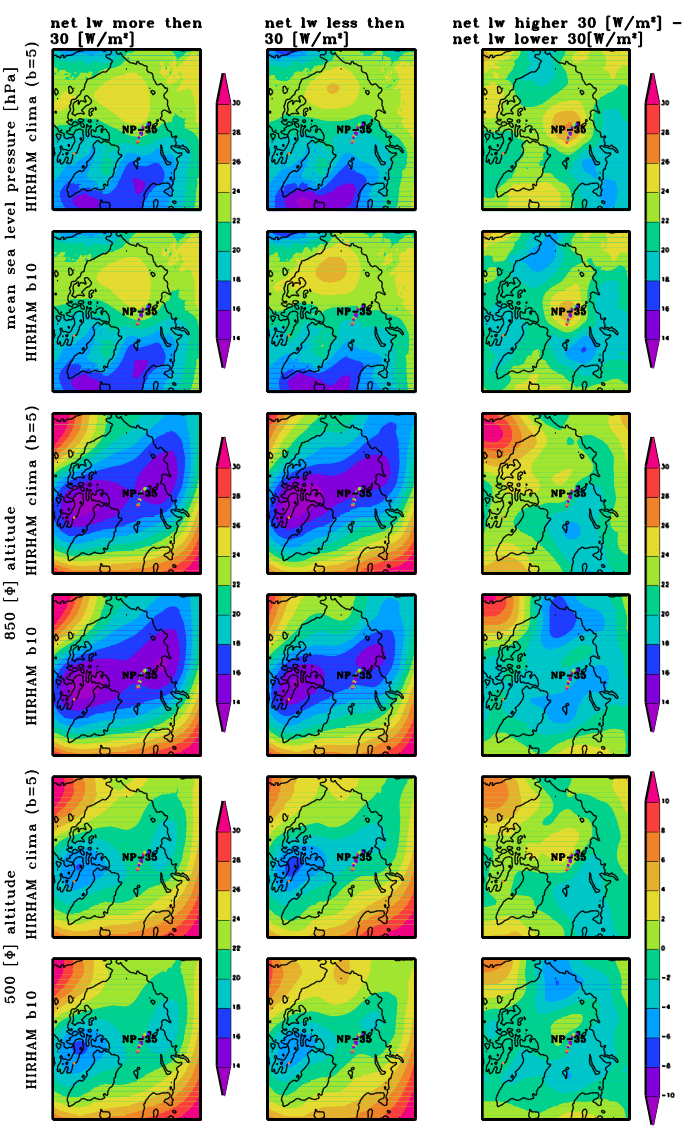

Fig. 11. Pan-Arctic distribution of mean sea level pressure (hPa) (first two rows), $850 \mathrm{hPa}(3$ and 4 rows) und $500 \mathrm{hPa}$ geopotential height fields (last two rows) (gpm) for HIRHAM clima, HIRHAM b10. Both are given for different LW radiation states (higher or lower $30 \mathrm{Wm}^{-2}$ ). The most right column shows the differences between both states. All at the NP-35 position averaged over November 2007 to March 2008

\section{ACPD}

$14,11855-11893,2014$

Atmospheric winter conditions 2007/08

M. Mielke et al.

Title Page

Abstract

Conclusions

Tables

14

Back

Full Screen / Esc

Printer-friendly Version

Interactive Discussion 

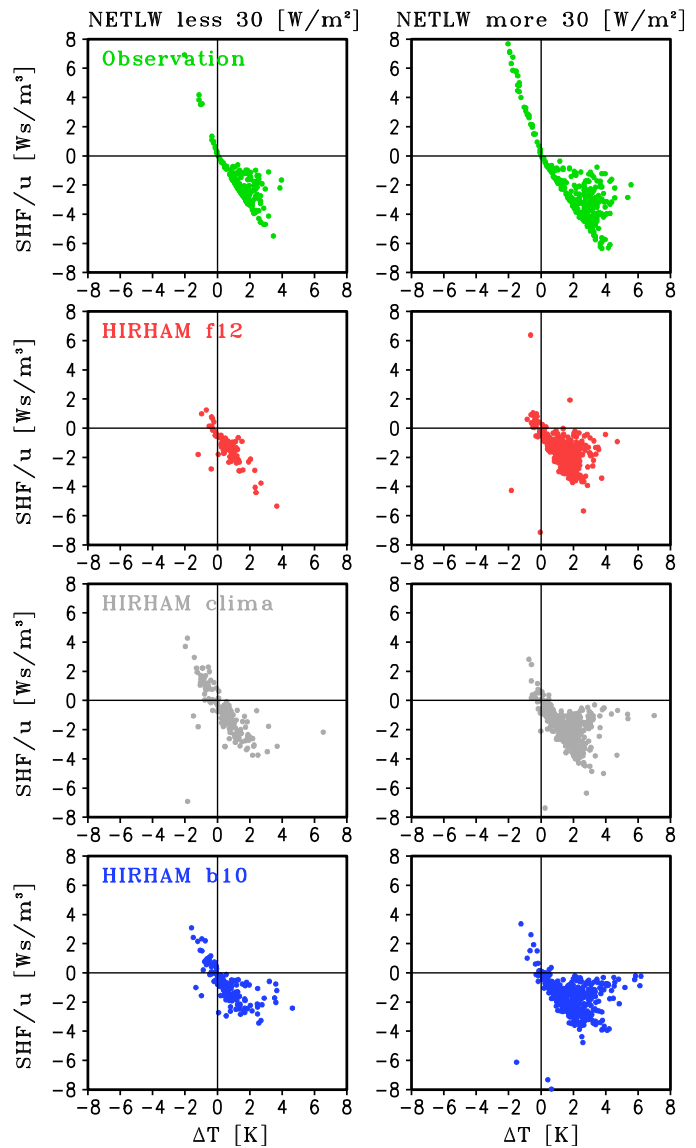

Fig. 12. Relation between wind-scaled sensible heat flux (SHF/u) and air-surface temperature difference $(\Delta T)$ with respect to the two net LW radiative states for November 2007-March 2008, applying the Zilitinkevich parameterizations to NP-35 data (green), HIRHAM f12 (red), HIRHAM clima with $b=5$ (grey) and HIRHAM b10 sensitivity run with $b=10$ (blue).

\section{ACPD}

14, 11855-11893, 2014

Atmospheric winter conditions 2007/08

M. Mielke et al.

Title Page
Abstract

Conclusions

Tables

14

4

Back Introduction References

\section{Figures}

$\rightarrow$

$\triangleright$

Close

\section{Full Screen / Esc}

Printer-friendly Version

Interactive Discussion 


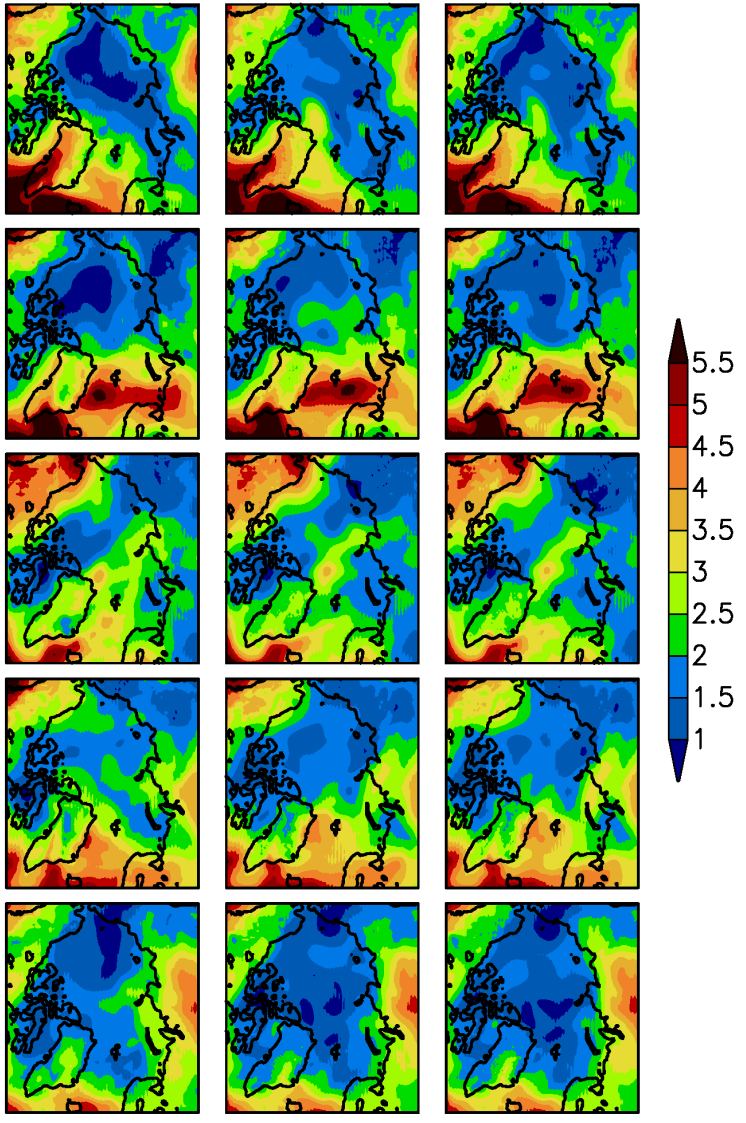

Fig. 13. Pan-Arctic distribution of synoptic-scale variability on time scales from 1-3 days expressed as filtered temporal standard deviation of 6 hourly mean sea level pressure $(\mathrm{hPa})$ for November 2007 (upper row) until March 2008 (lower row) and December, January and February in between. From left to right ECMWF operational analyses, HIRHAM clima with $b=5$, and the HIRHAM b10 with $b=10$ simulations.

\section{ACPD}

$14,11855-11893,2014$

Atmospheric winter conditions 2007/08

M. Mielke et al.

Title Page
Abstract

Conclusions

Tables

14

Back

Full Screen / Esc

Printer-friendly Version

Interactive Discussion 

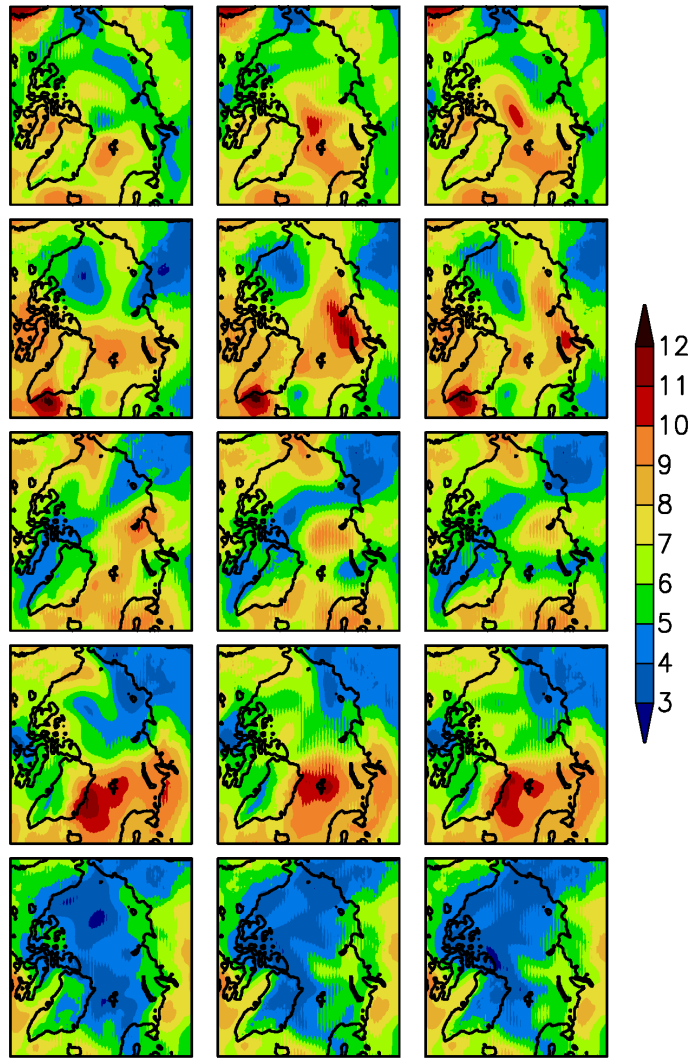

Fig. 14. Pan-Arctic distribution of baroclinic-scale variability on time scales from 2-10 days expressed as filtered temporal standard deviation of 6 hourly mean sea level pressure (hPa) for November 2007 (upper row) until March 2008 (lower row) and December, January and February in between. From left to right ECMWF operational analyses, HIRHAM clima with $b=5$, and the HIRHAM b10 with $b=10$ simulations.

\section{ACPD}

$14,11855-11893,2014$

Atmospheric winter conditions 2007/08

M. Mielke et al.

Title Page

Abstract

Introduction

Conclusions

References

Tables

Figures

14

$\rightarrow$

4

Back

Close

Full Screen / Esc

Printer-friendly Version

Interactive Discussion 

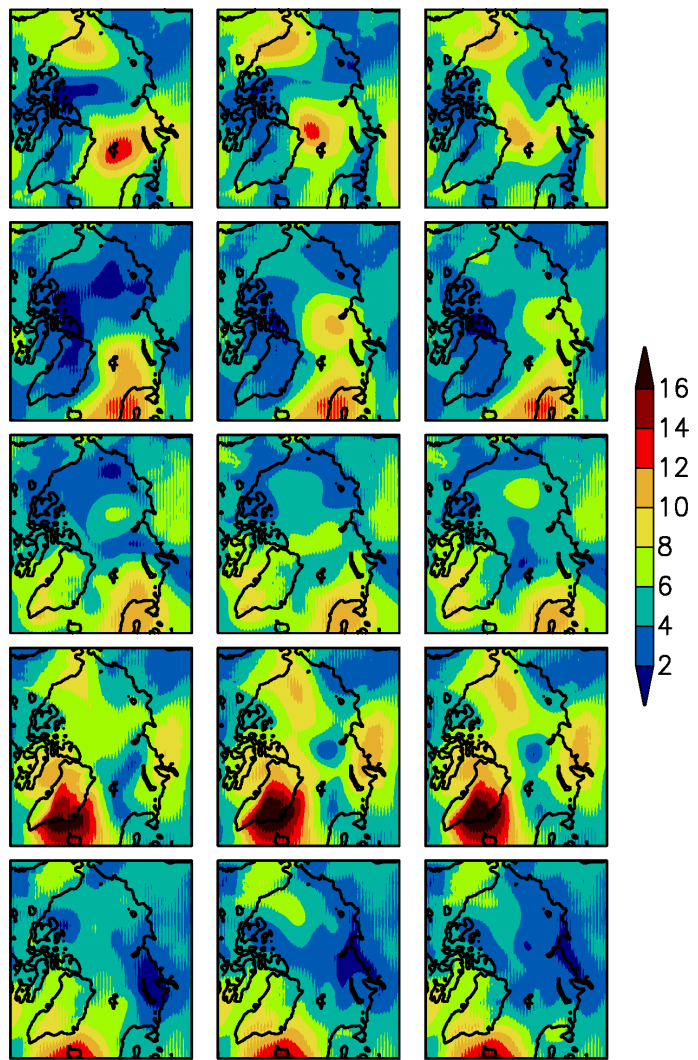

Fig. 15a. Pan-Arctic distribution of planetary-scale variability on time scales from 10-20 days expressed as filtered temporal standard deviation of 6 hourly mean sea level pressure ( $\mathrm{hPa}$ ) for November 2007 (upper row) until March 2008 (lower row) and December, January and February in between. From left to right ECMWF operational analyses, HIRHAM clima with $b=5$, and the HIRHAM b10 with $b=10$ simulations.

\section{ACPD}

14, 11855-11893, 2014

Atmospheric winter conditions 2007/08

M. Mielke et al.

Title Page

Abstract

Introduction

Conclusions

References

Tables

Figures

14

DI

4

Back

Close

Full Screen / Esc

Printer-friendly Version

Interactive Discussion 

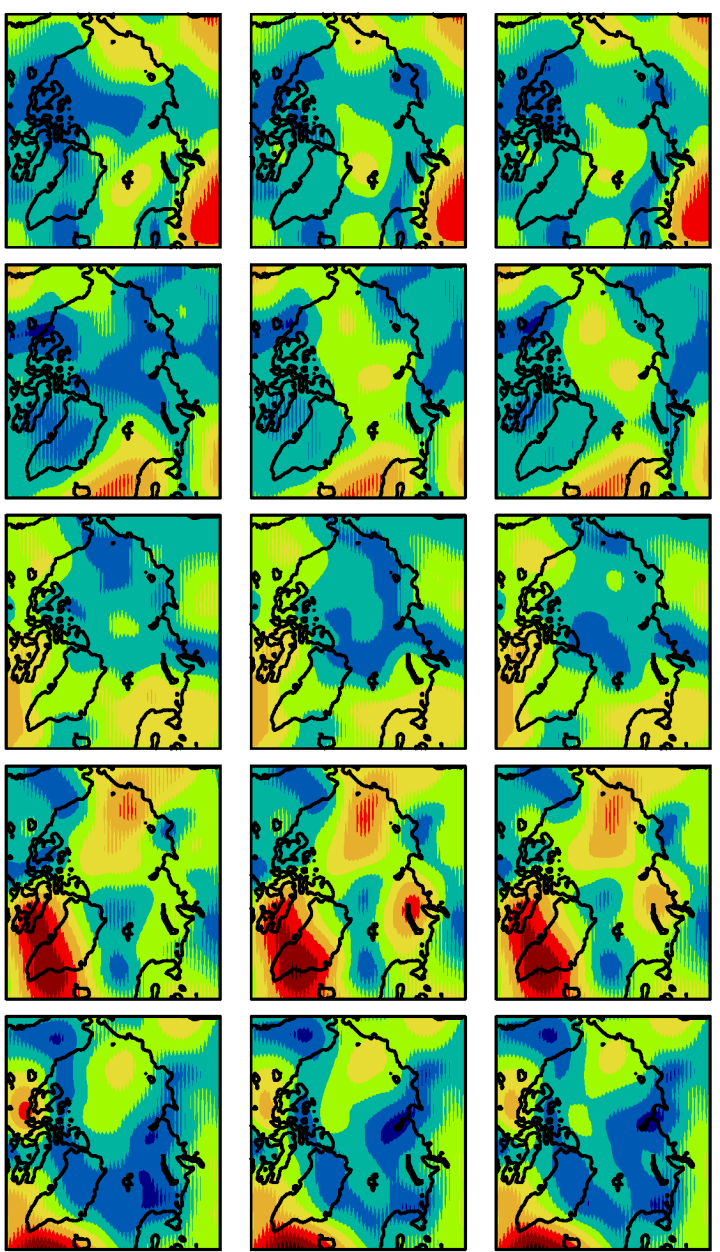

Fig. 15b. Same as in Fig. 15a, but for $500 \mathrm{hPa}$ geopotential heights (gpm).
ACPD

$14,11855-11893,2014$

Atmospheric winter conditions 2007/08

M. Mielke et al.

Title Page

Abstract

Introduction

Conclusions

References

Tables

Figures

14

$>$ I

4

Back

Close

Full Screen / Esc

Printer-friendly Version

Interactive Discussion

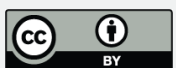

